\title{
National Culture and Bank Deposits
}

DOI:

http://dx.doi.org/10.1561/114.00000005

\section{Document Version}

Accepted author manuscript

Link to publication record in Manchester Research Explorer

\section{Citation for published version (APA):}

Mourouzidou-Damtsa, S., Milidonis, A., \& Stathopoulos, K. (2021). National Culture and Bank Deposits. Review of Corporate Finance, 1(1-2), 181-221. https://doi.org/10.1561/114.00000005

\section{Published in:}

Review of Corporate Finance

\section{Citing this paper}

Please note that where the full-text provided on Manchester Research Explorer is the Author Accepted Manuscript or Proof version this may differ from the final Published version. If citing, it is advised that you check and use the publisher's definitive version.

\section{General rights}

Copyright and moral rights for the publications made accessible in the Research Explorer are retained by the authors and/or other copyright owners and it is a condition of accessing publications that users recognise and abide by the legal requirements associated with these rights.

\section{Takedown policy}

If you believe that this document breaches copyright please refer to the University of Manchester's Takedown Procedures [http://man.ac.uk/04Y6Bo] or contact uml.scholarlycommunications@manchester.ac.uk providing relevant details, so we can investigate your claim.

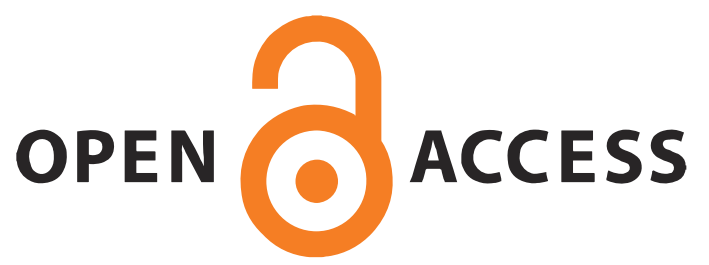




\title{
National Culture and Bank Deposits
}

Stella Mourouzidou-Damtsa, Andreas Milidonis, Konstantinos Stathopoulos*

Review of Corporate Finance, forthcoming

\begin{abstract}
This paper investigates the relation between national culture and bank deposits. Using annual data (1995-2015) for 99 banks that participated in the 2014 stress tests of the European Banking Authority, we document relations between three national cultural traits and bank deposits. The effect of hierarchy and individualism on deposits is stronger (positive and negative, respectively) in domestic banks where culture is more homogeneous compared to global banks. On the other hand, the positive effect of trust on deposits is robust for both domestic and global banks, reinforcing the view that banking is largely based on trust. Results are robust to empirical specifications alleviating endogeneity concerns, thus suggesting a causal effect. Motivated by recent regulatory changes emphasizing the importance of liquidity (deposit) stability, we further analyse the impact of annual bank-level deposit stability on the trustdeposits relation. We show that high deposit volatility is associated with a decrease in the positive effect that trust has on deposit levels.
\end{abstract}

Keywords: Deposits, national culture, trust, individualism, hierarchy, risk.

*Mourouzidou-Damtsa is a DBA graduate of the Alliance Manchester Business School, The University of Manchester and works for a European bank. Milidonis is at the Department of Accounting and Finance, Faculty of Economics and Management, University of Cyprus. Stathopoulos is at Alliance Manchester Business School, The University of Manchester. Corresponding Author: Stella Mourouzidou-Damtsa, stella.mourouzidoudamtsa@postgrad.manchester.ac.uk 


\section{Introduction}

Bank deposit levels are of primary importance to bank liquidity and stability. During the recent financial crisis, when liquidity dried up, even well-capitalised banks drawing funding from short-term and unstable sources, experienced severe difficulties. ${ }^{1}$ Central banks' intervention restored liquidity to the financial markets and at the same time highlighted the importance of bank liquidity management to the financial sector stability and well-functioning. More recently, the importance of bank liquidity has been emphasised by two relatively new regulations in Europe: (a) the Net Stable Funding Ratio (NSFR) ${ }^{2}$ introduced in January 2018; and (b) the Liquidity Coverage Ratio (LCR) ${ }^{3}$ enforced in January 2015. The level of customer deposits carries high weights (up to 95\%) in the calculation of the two ratios, which measure funding stability and short-term liquidity resilience. While the importance of deposits for banks is evident, the relation between the level of bank deposits and country-level characteristics, such as national cultural traits, is relatively unexplored in the finance literature.

As an example of the importance of deposits, consider the events in Cyprus since 2013. In March 2013, Cyprus experienced its biggest banking crisis, which resulted in the acquisition of the second largest bank by the first largest bank in Cyprus, a haircut on deposits of these two banks and capital controls being imposed for the first time in a Eurozone country from March 2013 until April 2015 (Michaelides, 2014). More recently, in the first half of 2018, rumours about the potential failure of the second largest locally systemic bank in Cyprus (Cyprus Cooperative Bank Ltd, “CCB”), whose deposits were almost exclusively held by local, individual depositors, led to an extended run on deposits from January 2018 until early July

\footnotetext{
${ }^{1}$ https://www.ecb.europa.eu/pub/pdf/mobu/mb201304en.pdf

${ }^{2}$ Basel III guidelines require banks to maintain a sustainable funding structure, and to this effect, they introduced the Net Stable Funding Ratio (NSFR) which became a minimum standard on 1 January 2018 (http://www.bis.org/bcbs/publ/d295.pdf).

${ }^{3}$ http://www.bis.org/publ/bcbs238.pdf
} 
2018. According to the former CEO of the CCB, in the first three months of 2018, the CCB lost about $€ 1.6$ billion in deposit outflows (about $50 \%$ of total CCB deposits), where the daily outflows experienced in the last days of March 2018 were even larger (averaging about 100 million euros per day) than any daily deposit outflow experienced in year $2013 .{ }^{4}$ Despite a deposit injection by the Cyprus government into CCB, the daily deposit outflows peaked again in early July 2018, immediately before the government's decision to break down the CCB into a good bank (sold to another local, systemic bank) and a bad bank, resulting in a total cost to the taxpayer of 3.2 billion euro (15.5\% of GDP; Fitch, $2018^{5}$ ). One interpretation of these events is that the 2013 events, where depositors' money was used to recapitalize the largest bank in Cyprus, were still fresh in the minds of local depositors in 2018, therefore the rumours about the potential collapse of the CCB might have reignited local depositors' concerns about deposit outflows, similar to those in 2013.

In this paper, we examine the relation between three national culture characteristics and the level of bank deposits in Europe. The level of deposits is determined by supply of available cash (i.e., from customers) and demand for cash (i.e., from bank management). On one hand, customers decide whether to place their excess wealth on deposit, versus any other financial instruments (e.g., invest in bonds or equity), or even spend it. On the other hand, bank managers have the discretion to decide the amount of liquidity to draw from clients' deposits versus other sources (e.g., the interbank market or other marketable securities). We conjecture that national culture affects local customers' and managers' decisions, inspired by the vast literature documenting an association between culture and financial decision-making, such as investment

\footnotetext{
${ }^{4}$ According to the same article (https://www.stockwatch.com.cy/el/article/trapezes/skt-ypirxan-efialtikes-ekroeskatatheseon-ton-martio; article in Greek), the deposit outflows neither left the country, nor did they enter other local banks in Cyprus, suggesting that the withdrawn deposits were kept "under the mattresses".

${ }^{5}$ https://www.fitchratings.com/site/pr/10048807
} 
decisions (Guiso et al. 2006), trading volume, volatility and momentum profits (Chui et al. 2010), syndicated bank loans (Giannetti and Yafeh 2011), corporate risk, (Li et al. 2013), mergers and acquisitions (Ahern et al. 2015), and financial intermedition (Aggarwal and Goodell, 2009). Kanagaretnam et al. (2014) find that differences in national cultures affect both accounting conservatism and risk-taking in banks. Thakor (2016) reviews the literature on culture in banking and finds that corporate culture may effectively support bank growth strategies as well as enhance financial stability.

Following Ahern et al. (2015), we focus our analysis on three national culture values: trust, individualism, and hierarchy. Trust is possibly the most important cultural trait for banks, particularly for attracting deposits. Sapienza and Zingales (2012), present the results of a survey around the 2008 crisis in the US to show evidence consistent with the interpretation that a decline in trust over this time period, is associated with a contemporaneous decline in economic activity. Moreover, trust in the banking sector is a commonly referenced term among regulators ${ }^{6}$, the financial press ${ }^{7}$ and large consulting firms. ${ }^{8}$ We take our analysis a step further by examining whether elevated, historical deposit volatility can affect the relation between trust and deposit levels.

The second cultural trait is individualism. Individualistic people value their interests more than the welfare of the group (Brett et al., 1998). They are typically optimistic and believe they can exercise control over future outcomes (Hofstede, 2001; Breuer et al., 2012). People who are optimistic about the future, feel that they are in control over their lives and can address financial problems. Consequently, we expect that individualistic societies will save less. Moreover, bank managers in individualistic societies may opt for quick funding originating

\footnotetext{
${ }^{6}$ https://www.fca.org.uk/news/debating-trust-and-confidence-in-banking-

7 http://www.bbc.co.uk/news/business-29046605

${ }^{8}$ http://www.ey.com/GL/en/Industries/Financial-Services/Banking---Capital-Markets/Global-consumer-bankingsurvey-2014--Trust-and-Confidence
} 
from the interbank market or securitisation, as opposed to the gradual building of customer relationships, a necessary element for attracting deposits (Harker et al., 2000).

The third cultural characteristic is hierarchy. Hierarchical societies organise themselves in groups according to status (Schwartz, 1994) with higher ranks seen as the role models to follow (Geoffrey and Kamel, 2004). We consequently anticipate lower ranks to follow higher ranks in their investment choices. Evidence of sequential depositor behaviour is provided by Iyer and Puri (2012) and Kiss et al. (2014). Furthermore, hierarchical societies are by nature less optimistic compared to egalitarian societies (Schwartz, 1994), consequently spend less (Manos et al., 2015) and prefer low-risk investments, such as deposits, compared to higher-risk investments (Guiso et al., 2008). Hence, we anticipate a positive association between hierarchy and deposits.

We construct our sample following Acharya and Steffen (2015) by focusing on the banks selected by the European Banking Authority to perform the 2014 stress tests, which operate in a relatively homogeneous regulatory framework. We keep those banks with available annual data over at least five consecutive years over the period 1995-2015. The final sample comprises 99 European banks with 1308 firm-year observations, all of which are systemically important either domestically or globally, representing over $70 \%$ of the assets of the European banking sector. ${ }^{9}$ These banks operate under a common regulatory framework; that is, the European Central Bank (ECB) regulates them either directly, or indirectly through the domestic central banks. We match this sample with the national culture variables available from the World Values Survey database to test our hypotheses.

\footnotetext{
${ }^{9}$ A domestic systemically important bank in the Eurozone, represents one of the large banks domiciled in a Eurozone country, whose potential failure would likely impact the financial stability of the specific country but not necessarily the global financial system. One such example would be the "Bank of Cyprus" in Cyprus. On the other hand, the failure of a globally systemically important bank in the Eurozone, would likely impact the global financial system. One such example would be Deutsche Bank in Germany.
} 
Given the different layers of variables in our sample (i.e., countries, banks and bank-years), we use multi-level regressions of bank deposit levels on the three cultural characteristics, after controlling for individual bank performance, country-level economic performance and institutional quality characteristics. We find a statistically significant association between all three cultural characteristics and the level of bank deposits. Consistent with our hypotheses, we find that trust and hierarchy are positively related to the level of bank deposits, while individualism has a negative relation.

National culture is expected to have a larger impact on deposits in banks that have more culturally homogeneous customers and employees, than those who operate in a more culturally diverse environment. Hence, we split our sample into domestic and global banks (Edwards 2012). Domestic banks typically draw deposits domestically whereas global banks operate in many countries hence draw deposits from customers around the world. Moreover, global banks are directly supervised by the European Central Bank while domestic banks are supervised through national central banks, which could be further influenced by national culture when monitoring domestic banks or implementing transnational regulations. Consistent with our expectation, we find that the impact of cultural variables is stronger in domestic instead of global banks. Specifically, we find a relation between all three cultural variables and the level of bank deposits for domestic banks. In the case of global banks, we only document a positive association of deposit levels and trust (no relationship appears for either individualism or hierarchy), lending support to the popular view that banking is largely based on trust.

Given the robust positive relation between trust and deposit levels, across the samples of domestic and global banks, and motivated by recent regulatory changes to encourage deposit stability, we extend our analysis to identify any potential links between trust and deposit levels. To do this, we investigate if banks operating in the same cultural environment (with respect to 
trust) experience cross-sectional heterogeneity with respect to other factors that may amplify or dampen the association between trust and bank deposit levels. Specifically, we focus on bank historic deposit volatility (over a five-year horizon), where high volatility would be perceived as a signal of instability in customer relationships. We find that the positive relation between trust and bank deposit levels is reduced in the presence of high deposit volatility. The size of this reduction is economically significant. Furthermore, this result is robust across the entire sample, but also the subsamples of domestic and global banks.

Cultural characteristics can be thought of as entreched within a society, much earlier than the beginning of our sample period. Specifically, Guiso et al. (2006) define national culture as 'customary beliefs and values that ethnic, religious, and social groups transmit fairly unchanged from generation to generation.' Still, while it is unlikely that bank deposit levels will affect a society's cultural traits, that is, reverse causality is unlikely to be present, we conduct robustness tests using alternative measures of culture that do not change over time (i.e., Hofstede, 1980) and find similar results.

To address concerns about the impact of omitted variables in our models, we include an extensive range of country-, bank- and institutional quality factors, as well as year fixed effects. Furthermore, to make the case for a causal interpretation of our results, we identify instrumental variables from the literature to proxy for the three national culture characteristics and conduct two-stage least squares (2SLS) regressions. The instruments we use are Religion, Ethnicity and Language fractionalization variables (Alesina et al., 2003) as well as Geography (Kwok and Solomon, 2006). Our results are robust to this specification, lending further support to the causal relation between cultural characteristics and bank deposit levels, while minimizing concerns related to omitted variables. 
Our paper contributes to several strands of literature. Specifically, it builds on prior work examining bank funding stability (Schlueter et al., 2015), national culture and corporate cash holdings (Chen et al., 2015), as well as national culture and national savings (Manos et al., 2015). Schlueter et al. (2015) examine the behaviour of retail customers regarding nonmaturing deposits and how these can be managed by banks using pricing incentives, however, without examing the impact of cultural characteristics. Chen et al. (2015) examine the impact of national culture on corporate cash savings around the world. Manos et al. (2015) investigate the impact of culture on the individual's rate of aggregate savings' decisions. Our paper differs from these prior studies in several ways. First, we focus on banks, a highly regulated sector, and examine the bank level deposit variation, not the individual, corporation or country cash holdings. Second, we separately test the association between culture and bank deposit levels for domestic and global banks and find more significant impact where cultural factors are more homogeneous. With the exception of trust that has a universal, robust, positive relation with bank deposits for both domestic and global banks, individualism and hierarchy seem to affect deposit levels only for domestic banks. Our work also differs in that our analysis addresses revese causality and omitted variable concerns, while also covering a more recent time-series from 1995 to 2015. Third, we provide evidence that prior deposit instability (measured using elevated deposit volatility) is associated with a decrease in the positive effect that trust has on deposit levels.

Our paper has public policy implications. Figure 1 shows that there is high variability in cultural characteristics among countries, supporting the view that Europe is a political and economic union, consisting of countries maintaining their unique cultural identity. Consequently, these countries behave differently under similar conditions, for example, under 
the same regulatory framework. ${ }^{10}$ Hence, this paper aims to create awareness to bank management, customers and regulators that cultural characteristics are associated with financial decisions (e.g., level of bank deposits). When choosing their liquidity sources, bank managers should know that their deeply rooted cultural traits are influencing their decisions. The same applies to depositors when deciding whether to save or consume their excess wealth. All banks in Europe operate under a single rule book and are supervised by the same authorities. Uniformity of regulation, however, does not imply consistency in enforcing them and consequently does not produce the same results across cultures.

The rest of this paper is organized as follows. Section 2 provides the institutional framework and develops the hypotheses. Section 3 describes the data collection and variable construction process. The methodology and empirical results are described in section 4 while robustness checks are provided in section 5 . Section 6 concludes.

\section{Institutional Framework and Hypotheses Development}

\subsection{Institutional Framework: Why do banks need deposits?}

In their need to manage their funding demand curve, banks use several liquidity options available to them. Among the most common liquidity options are the following: customer deposits, the interbank market, sovereign bonds and money market funds via debt issuance. According to Basel III, banks need to maintain stable funding, safeguarding them from liquidity drainages during financial crises. Hence, banks place emphasis on the more stable of the above liquidity options. The recent financial crisis highlighted the fact that the interbank market,

\footnotetext{
${ }^{10}$ A recent example related to failing banks in different countries within Europe is how Italy and Cyprus treated their failing banks. While on one hand Cyprus abided by the European Bank Recovery and Resolution Directive (BRRD) resolution (or bail-in directive), and bailed-in its largest domestically systemic bank, on the other hand, Italy did not follow the bail-in directive and bailed out its failed banks.
} 
sovereign bonds and money market funds become scarcer than customer deposits as a liquidity option to banks during adverse macro events. ${ }^{11}$

The fact that customer deposits constitute one of the most important and stable liquidity vehicles for banks, is also echoed in two recent regulations. First, deposits are at the spotlight of the existing Liquidity Coverage Ratio (LCR) requirement, ${ }^{12}$ which requires banks to keep a minimum ratio of $60 \%$ since 2015 , which increased to $100 \%$ in 2019 . The second regulation is the Basel III Net Stable Funding Ratio (NSFR), which places more emphasis on customer deposits as a form of stability of bank liquidity than certain wholesale options such as leverage via securitisation, for example, attracting liquidity by issuing corporate bonds.

Another reason banks need deposits is to transform illiquid investments into liquid ones by funding viable projects to facilitate economic growth (Levine and Zervos, 1998; Beck et al., 2000; Beck and Levine, 2004; Goldstein and Pauzner, 2005). Allen and Santomero (2001) challenge the financial intermediation role of banks claiming that deposits are losing importance for banks over time because banks tend to engage more in investment management than attracting deposits. However, Allen and Parwada (2004) find that traditional banking activities, such as attracting deposits, are still necessary for banks because they have to comply with prudential regulatory requirements. Instead, non-traditional banking activities, for example, investment management, are only used as complements to traditional banking activities.

\footnotetext{
${ }^{11} \mathrm{https}: / /$ www.ecb.europa.eu/pub/pdf/other/eubanksfundingstructurespolicies0905en.pdf

12 The LCR is defined in the following document by the Bank of International Settlements (page 12, point 22): http://www.bis.org/publ/bcbs238.pdf.
} 


\subsection{Hypotheses Development}

Given the importance of a stable deposit level for banks, it is then natural to ask whether differences in culture among countries affect banks' efforts to attracting deposits. While, for example, some banks engage in customer segmentation aiming at building strong relationships with customers, ${ }^{13}$ customers' likelihood to choose deposits over consumption or over riskier investments (e.g., equity) might be determined by a series of factors deeply rooted in national culture. Hence, we aim to identify cultural characteristics that correlate with deposit levels in our sample of multiple countries and respective cultures. Controlling for factors such as bank characteristics and country economic performance, we examine the impact of three unique cultural characteristics that are expected to impact the levels of deposits in banks. These are Trust, Individualism, and Hierarchy. We develop our hypotheses around these three national cultural characteristics in subsections 2.2.1, 2.2.2 and 2.2.3, respectively.

\subsubsection{Trust}

We consider Trust to be the most important cultural dimension related to bank deposit levels. Trust captures the belief by one party that another party is reliable and will deliver on their promises. In our context, we interpret customers' trust towards banks to imply that customers keep their deposits at a bank because they believe that, upon maturity of the deposit certificate, they will receive their money back in full, plus any interest due on the deposit certificate.

\footnotetext{
${ }^{13}$ One example adopted by banks to attract and retain valued depositors is to segment the customer base based on the amount of deposits, and awarding a "premier" status to those customers with the highest deposit balance (a strategy adopted by HSBC, Barclays, Bank of Ireland, among others). Another way is to offer rewards or incentives to depositors through advanced retail analytics, given the amount of information banks collect on their existing or new customers.
} 
The importance of trust is documented in the literature. Lyons and Mehta (1997) establish that contracts are facilitated by trust, hence, since deposit certificates are a formal contract between the customer and the bank, trust should play a role in the level of deposits. In addition to facilitating contract formation, trust is also described as a social capital component facilitating economic transactions (Putnam, 2000). Furthermore, trust enables financial success, performance, and economic growth, both for society and firms (Fukuyama, 1995), but also promotes cooperation among firms (La Porta et al., 1997). ${ }^{14}$ Finally, customer trust is important for banks as it increases satisfaction (Morgan and Hunt, 1994) as well as customer loyalty (Dwayne et al., 2004) and consequently leads to enhanced retention rates as well as potential growth rate. Hence, we formally state our first hypothesis based on trust:

H1 Trust and bank deposit levels are positively associated.

\subsubsection{Individualism}

The second cultural characteristic we examine is Individualism. Hofstede (2001) defines individualism as the preference to take care of oneself and their immediate families. People in individualistic cultures typically place their welfare above that of the group. They are normally very optimistic about the future (Fischer and Chalmers, 2008), often overestimating their control over future outcomes (Van Den Steen, 2004). Saving money is sensible, it provides stability during unexpected events such as job loss and entails less risk because deposits are less volatile compared to other investments. Saving befits collectivist people (the opposite of individualistic) who are likely to care more about the 'we' rather than the 'I', acting prudently for the welfare of their group (Chen et al., 2015; Hofstede, 1980).

\footnotetext{
${ }^{14}$ In more recent work related to trust and saving behavior, Coupé (2011) studies peoples’ decision to save their money as cash at home vs. saving at a bank. Using survey data from Ukraine, Coupé finds that people who trust banks less are expected not to save their money in bank deposits. However, results from a developing country like Ukraine may not echo results in countries that typically have higher institutional quality.
} 
On the relation between individualism and the management of a firm, Van Hoorn (2014) finds that individualistic bank managers tend to be more optimistic. They place their interests above the interest of the group. Hence, they may consequently decide to invest fewer resources in building relationships with customers to enhance the deposit-based business of the bank and opt for the readily available wholesale funding options instead. Therefore, we expect fewer deposits when managers are characterised by individualism.

Moreover, customers with excess liquidity living in individualistic societies are expected to have a similar, optimistic view of the future. Therefore, such customers are expected to save less and consume more today. The expectation that both bank managers and consumers behave in a way that leads to lower deposit levels in more individualistic societies compared to less individualistic societies, informs our second hypothesis:

H2 Individualism and bank deposit levels are negatively associated.

\subsubsection{Hierarchy}

The third cultural characteristic we focus on is Hierarchy. Hierarchy is a dimension included in the cultural sets of Hofstede (1980), Fiske (1991), Schwartz (1994) and Trompenaars (2012). In hierarchical societies, each member assumes their role in a hierarchical structure (Schwartz, 1994). Lower ranking members typically turn to the higher-ranking members for important decisions (Geoffrey and Kamel, 2004), for example, the decision of choosing a bank to place their deposits. Further evidence is provided by Kiss et al. (2014) who find that depositor behaviour is partially sequential and many of them follow other depositors in their decisions (Iyer and Puri, 2012). We expect this phenomenon to be more profound in hierarchical societies, where depositors who are lower ranking on the societal scale are expected to follow higher ranking depositors in their investment choices. 
To examine the relation between hierarchy and saving behaviour, it is useful to understand the literature on hierarchy and conservatism. Specifically, Schwartz (1994) finds that hierarchy is highly correlated with conservatism. Moreover, Manos et al. (2015) find that when people are more conservative, they are likely to save more and spend less. In addition, Guiso et al. (2008) find that more conservative people are expected to allocate more on bank deposits and less on other forms of investments given the lower risk inherent in bank deposits relative to other investments. Therefore, we expect that more hierarchy should be correlated with more deposits given that (a) hierarchy is correlated with conservatism, (b) conservatism is associated with saving more today (vs. consuming) and (c) saving in hierarchical societies typically takes place in low risk investments (e.g., deposits vs. riskier investments).

H3 Hierarchy and bank deposit levels are positively associated.

\section{Data and variables}

To test our hypotheses, we follow the approach of Acharya and Steffen (2015) to use a sample of systemic financial institutions, which were included in the European Banking Authority (EBA) stress tests. ${ }^{15}$ The EBA stress tests evaluate the ability of banks to withstand adverse conditions and also contribute to the overall assessment of systemic risk in the EU financial system. These institutions contribute approximately $50 \%$ to the domestic banking sector of each country and more than $70 \%$ of the total European banking assets (about $€ 29$ trillion). These banks are systemically important either domestically or globally; hence, when in financial turmoil the consequences are severe and transmitted to their corresponding sovereigns or the global financial system (Acharya et al., 2014). The major advantage of this

\footnotetext{
${ }^{15}$ https://eba.europa.eu/documents/10180/563711/31012014+EUwide+stress+Test+2014+\%28List + of + sample+banks+\%29.xlsx
} 
sample is that it is rather homogeneous in terms of regulation and supervisory authorities, therefore minimizing heterogeneity concerns and potential confounding effects in the analysis.

To build our final sample, we collect those banks included in the EBA stress tests for which there are data in Bloomberg for at least five consecutive years. Our entire time-series covers a twenty-one-year period, from 1995 to 2015. The dependent variable we use to capture the level of deposits, is the ratio of customer deposits scaled by the bank's assets (Deposit level), following Acharya and Naqvi (2012) and Chen et al. (2015).

\subsection{National culture variables}

We use the Individualism, Trust and Hierarchy scores from the World Values Survey; a global network of social scientists studying the impact of culture. The survey takes place in waves in approximately 100 countries and covers roughly $90 \%$ of the world's population with the same questionnaire. ${ }^{16}$ Academic research using this survey has been growing (e.g., La Porta et al., 1997; Glaeser et al., 2000; Sapienza et al., 2013; Ahern et al., 2015). We use the same proxy questions as Ahern et al. (2015) for Individualism, Trust, and Hierarchy (see the Data Appendix for more details). Following Ahern et al. (2015), we divide survey scores (which originally vary from $0-10$ ) by ten thus producing a variable bounded between zero and one. It is important to note that correlations among the three national cultural characteristics are not statistically significant, which reinforces the view that they capture different cultural dimensions.

\footnotetext{
${ }^{16}$ The survey is conducted every few years. Specifically, over our sample period, the survey covers the following periods: 1999-2004, 2005-2009 and 2010-2014. To have a complete panel, we assume that the survey values for the most recent survey apply.
} 


\subsection{Control variables}

We use three major groups of control variables that might affect deposit levels: (a) bank financial variables; (b) country-level economic performance variables; and (c) institutional quality and governance variables. The next three subsections explain our rationale in choosing these variables (The Data Appendix provides their detailed definitions).

\subsubsection{Bank Financial Variables}

The first control variable we use is Net Interest Margin. Banks adjust their interest rates to attract and retain deposits (Calem and Carlino, 1991). Starting from the interest rate policy of the European Central Bank, bank management may or may not decide to pass on these rates to its deposit pricing (Allen and Santomero, 2001; Hofmann and Mizen, 2004; Boyd and De Nicollo, 2005). Dothan and Williams (1980) provide further evidence that the bank's management has some flexibility in their strategic decisions, including deposit collection and loan strategies. Customer deposits constitute the principal source of loanable funds for a bank, and consequently, lending rates feed back to deposit rates (Kiser, 2004). We include deposit and loan interest rates per bank in our analysis using the Net Interest Margin as a proxy.

We also control for the size of the financial institutions in our sample. Laeven et al. (2014) find that large banks draw less funding from deposits and more from alternative sources. Laeven et al. (2016) find that systemic risk grows with bank size.

Risk is another pivotal factor to banking operations. Banks assume risks (Jin and Zeng, 2014) to attain higher revenues, and the level of risk variation influences the bank's business model. Moreover, national culture is associated with bank risk (Kanagaretnam et al., 2011; Kanagaretnam et al., 2014; Mourouzidou-Damtsa et al., 2017). Banks assuming higher risk attract lower levels of uninsured deposits (Lambert et al., 2017). 
We next use Interest Activity to capture the extent of a bank's traditional banking operations. Savings are considered as the inputs and loans as the outputs of banking (Mester, 1987). Specifically, banks provide loans to individuals and firms funded by their customers' savings (Schumpeter, 1961).

Not all banks follow the traditional banking model above. Hence, to control for banking operations not directly linked to deposit-driven business, we construct and use the Wholesale Funding variable (Demirgüç-Kunt and Huizinga, 2010; Huang and Ratnovski, 2011; Craig and Dinger, 2013). Furthermore, since wholesale funding might be affected by counterparty default risk, we use the 3-month Euribor \% in our model as a proxy of counterparty risk. We choose Euribor as the proxy for this risk as most of our countries are in the Eurozone and also Euribor distrortions potentially affect the Libor as well (Dolan, 2008; Michaud and Upper, 2008). Finally, we control for the bank’s Loans to Assets ratio and Leverage.

\subsubsection{Country-Level Economic Performance Variables}

A country’s economic performance might affect the level of deposits in local banks. Specifically, Berger and Hannan (1989) associate the local per capita income with deposit balances. Hence, we control for both the Gross Domestic Product (GDP) per capita as well as the GDP growth per country (La Porta et al., 1997; Fiordelisi et al., 2011; Li et al., 2013; Anginer et al., 2014; Ahern et al., 2015).

Next, since interest rates affect the decision of households to consume or save their excess liquidity (Hutchison, 1995), we control for Consumption (as a percentage of GDP) and Savings (to national income) for each country. One of the elements factored in the decision of households when choosing between consumption and saving is the prevailing interest rates (Sandmo, 1970) via the substitution effect. The substitution effect argues that a high rate of 
interest makes consumption today more costly relative to future consumption and encourages households to substitute today's consumption with future consumption. In addition, we control for the Inflation in each country, as it affects the general macroeconomic environment within each country.

Finally, while our sample includes solely European banks, each country may have a different legal framework that may affect depositors' saving patterns. To account for legislative variants, we control for the Legal Origin of the country (La Porta et al., 1998).

\subsubsection{Institutional Quality and Governance Variables}

The degree of institutional and governance quality in each country can also have an influence on deposits. We first address the potential criticism that banks may be governed by different accounting standards and transparency frameworks by using the La Porta et al. (1998) and the Barth et al. (2013) indices which measure the transparency of financial statements (Financial Statement Transparency) and quality of accounting standards (Rating on Accounting Standards) per country (García-Kuhnert et al., 2015). Also, since publicly traded firms are likely to be more transparent, we include the Listed indicator to capture differences between listed and non-listed firms. In addition, we control for the La Porta et al. (1998) creditor's index (Creditor Rights), which measures the enforcement of the rules protecting the bank’s creditors (including depositors).

Next, we use the Barth et al. (2013) Capital Stringency Index to measure the bank's capital adequacy index under adverse conditions. We do this because capital adequacy 
influences the bank’s ability to attract uninsured deposits (Keeley and Furlong, 1990) as well as the cost at which a bank is able to attract deposits (Diamond and Rajan, 2000). ${ }^{17}$

Finally, as we examine the effects of culture, we also control for the nationality of the CEOs. Specifically, Domestic CEO measures whether the CEO is a national of the country in which the bank has headquarters.

\subsection{Descriptive Statistics}

Table 1 presents the summary and descriptive statistics (mean, median, standard deviation, $25^{\text {th }}$ percentile and $75^{\text {th }}$ percentile) of all variables used. We discuss only the main dependent variable and the three independent variables capturing national cultural characteristics, since the statistics for the control variables are consistent to those reported by prior literature.

Our dependent variable (i.e., the ratio of customer deposits to total assets), has a mean (median) of 0.409 (0.406), which means that customer deposits on balance sheet amount to approximately $41 \%$ of the total liabilities side. A more visual demostration of the variation in the average customer deposits scaled by total assets among countries in shown in Figure 2. Specifically, we observe the range of the dependent variable extending from 0.14 (Belgium) to 0.81 (Cyprus), while other countries on the low (high) end of the distribution are Finland, Germany and France (Malta, Hungary and Poland).

Turning to the main explanatory variables, we observe that the mean (median) value for Trust, Individualism and Hierarchy are 0.35 (0.31), 0.53 (0.55) and 0.49 (0.47) respectively. The standard deviation is 0.08 for Individualism and Hierarchy, whereas for Trust, the

\footnotetext{
${ }^{17}$ The deposit protection scheme applies for all European countries, and as such, we did not include it to our explanatory variables.
} 
deviation is higher and stands at 0.15 . These statistics demonstrate that while the European Union is an economic union, it is far from a cultural union, given the striking differences in cultural characteristics. A look at Figure 1 provides a visual confirmation of the European cultural diversity. Starting with Trust (Panel A), we observe that in most of the northern European countries Trust is relatively high compared to the rest of Europe (e.g., Cyprus and Portugal have the lowest values). Next, Hierarchy (Panel B) also has significant variation among countries (but less than Trust), where low scores describe countries such as Finland and Poland, and high scores describe countries such as Sweden and Germany. Finally, in the case of Individualism (Panel C), we note the highly individualistic societies of Malta, Denmark and Poland and the less individualistic societies of Greece and Austria.

\section{Estimation model and empirical results}

\subsection{Estimation Model}

To test our hypotheses, we use a multi-level linear regression framework. We do this following recent literature (Raudenbush and Bryk, 2002; Goldstein, 2011) because our dataset comprises of three different levels of variables: country-specific characteristics; bank-level characteristics; and multiple observations per bank (i.e., over time). The heterogeneity potentially introduced in the sample due to different levels of variables (e.g., country vs. banklevel data) is addressed in multi-level linear models by a series of methods such as weighing on each group’s sample size and interacting across levels (e.g., Li et al. 2013; Field, 2013).

To analyse the relation between culture and bank deposit levels, we use Customer Deposits to Total Assets as the dependent variable, and the three national culture variables (Trust, Individualism and Hierarchy) as the three main independent variables. Our control 
variables in this regression are grouped into bank performance, country economic performance and institutional quality variables. Specifically:

$$
\text { Bank deposit levels } y_{i, j, t}=\quad \alpha+\beta^{*}(\text { National Cultural Variables })_{j, t}+\gamma^{*}(\text { Controls })_{i, j, t}+
$$

$$
\text { Year fixed effects }+\varepsilon i, j, t
$$

where $y_{i, j, t}$ represents the bank deposits scaled by the total assets for bank $i$ in country $j$ at year $t$. Vector $\beta$ gives the coefficients of the three national culture scores for country $j$ at time $t$. Vector $\gamma$ gives the coefficients of the control variables for bank $i$ in country $j$ at time $t$. We add year fixed effects to control for deterministic time trends or macro effects over the 21-year period of our analysis.

\subsection{Results}

\subsubsection{Culture and Deposits}

In Table 2 we show the results of the multi-level linear regression depicted in Equation (1). Overall, we observe statistically significant relations for all three national culture variables, while controlling for bank, country and institutional quality characteristics. The direction of coefficients is consistent with our three main hypotheses.

Specifically, the coefficient of Trust is 0.118 and statistically significant at the $1 \%$ level, which indicates that deposit levels are higher in societies with higher recorded levels of trust, than societies with lower values. This result is consistent with hypothesis 1 and it intuitively suggests that consumers deposit their money in banks which operate in an enviroment (country) of higher trust. This result echoes findings in the literature which identify trust as a major factor in contract formation (Lyons and Mehta, 1997), but also in customer satisfaction (Morgan and 
Hunt, 1994) and customer loyalty (Dwayne et al., 2004). The size of the coefficient is also economically significant. A one standard deviation increase in Trust (0.145) is associated with a 0.017 increase in the level of bank deposits relative to average deposit levels (0.409). ${ }^{18}$

Next, we find that the coefficient of Individualism is -0.120 and also statistically significant at the $1 \%$ level, hence the prediction of hypothesis 2 is validated. This result implies that deposit levels are lower in more individualistic societies, compared to deposit levels in less individualistic societies. The direction of the coefficient is justified by the link between individualism and optimism (Fischer and Chalmers, 2008), where both bank managers and customers are expected to behave in deposit-reducing manner. This is because more individualistic societies typically have bank managers who invest less in building customer relationships (i.e., to attract deposits). Also, individualistic societies have consumers who are more optimistic about the future, thus saving (consuming) less (more) in the present. Individualism also has an economically significant effect on bank deposits. As an example, increasing Individualism by one standard deviation (0.84) is associated with a 0.01 decrease in bank deposit levels relative to average deposit levels (0.409).

We next move to the coefficient of Hierarchy, which is positive (0.177) and statistically significant at the $1 \%$ level. Similar to the previous two cultural variables, results for Hierarchy are consistent with the predictions of hypothesis 3. This result implies that in societies that are more hierarchical (people tend to follow higher ranking peoples’ actions), which are also typically described by conservatism, people tend to save (spend) more (less) in the present time vs. the future. Moreover, saving typically takes the form of investing in low risk investments such as bank deposits instead of financial instruments such as bonds or equity. Similar to the

\footnotetext{
18 To address potential endogeneity concerns, we repeat our analysis in a two stage least squares framework (section 5.3), where properly identified instrumental variables are employed. The economic significance of the results using the 2SLS framework is higher as reported in the relevant section.
} 
the other two cultural characteristics, results for Hierarchy also have an economically significant effect. Specifically, bank deposit levels seem to increase by about 0.014 when Hierarchy increases by one standard deviation (0.08), relative to average deposit levels (0.409).

While several of the control variables related to bank financials and institutional quality obtain significant coefficients, we note that most of the country-specific, economic performance, control variables do not seem to be related to the level of deposits. This is possibly due to the presence of year fixed effects that are likely removing much of the year-to-year variation in countries’ economic performance.

Starting with Wholesale Funding we observe a negative relation with deposit levels, which is statistically significant at the $1 \%$ level. The direction of this relation is in line with expectations given that wholesale funding is an alternative source of banking liquidity to bank deposits. Next, we find a negative association between Bank Size and deposits, consistent with existing literature (Laeven et al., 2016) who report that larger banks prefer less deposits and more wholesale funding. We also find a negative association between deposits and Risk. Riskier banks tend to have lower deposit levels, which is consistent with risk-averse customers choosing a safer bank to keep their deposits rather than a riskier one.

Leverage (equity scaled by total assets) has a negative correlation with deposits (significant at the $1 \%$ level). The direction of the coefficient is as expected since equity is among the most expensive ways to raise capital, and equity holders are likely to request a higher expected return on their investment (Allen et al., 2015). Hence, bank managers may be looking for a way to assume higher risks (than banks with lower leverage) to generate profits, thus shifting more risk onto consumers' deposits. Turning to Loans to Assets we obtain a positive coefficient (at the $1 \%$ statistical significance level), which is consistent with the fact that banks use deposits (liabilities) to offer loans (assets) (Allen and Santomero, 2001). 
Now focusing on the institutional quality and governance variables, we also observe results consistent with expectations. For instance, variables related to corporate transparency (Listed, Financial Statement Transparency) have a positive relationship with the level of deposits (both at the $1 \%$ statistical significance level) since more transparency is expected to attract more deposits. Creditor Rights also obtains a positive coefficient (at the $5 \%$ significance level), which is consistent with the explanation that in countries where there is more protection of investors (including depositors), there should be more investment in deposits (Freytag and Voll, 2013). Finally, the Capital Stringency Index, a proxy for well capitalised banks resistant to adverse economic conditions, has a positive association with deposit levels (at the $1 \%$ statistical significance level), since a more stable bank will likely have more deposits than a less stable bank.

\subsubsection{Culture and Deposits for Domestic vs Global Banks}

Our results from the previous section indicate that the three national culture variables have strong correlations with bank deposit levels. But what happens to bank deposit levels when a bank has a more culturally diverse customer base? In other words, if a bank has global operations and its customer base draws from several countries (or cultures), would we expect the above documented relations to weaken?

We expect the sample of global banks to behave differently than the sample of domestic banks for the following two reasons. First, global banks in our sample are supervised by a more senior supervisory body (i.e., the European Central Bank; ECB) than the supervisor of local banks (National Central Bank). ${ }^{19}$ This implies that national culture may play a more significant

\footnotetext{
${ }^{19}$ Reasons for the broader supervision of global banks include: (a) more market-based operations (compared to the more traditional banking model based on deposits and loans); (b) more organisationally complex (in terms of subsidiaries around the globe); and (c) less stable funding and less capital (Laeven et al., 2014; Laeven et al., 2016).
} 
role through the degrees of freedom that the domestic regulator (National Central Bank) has, since both regulator and bank management are more likely to be affected by domestic cultural traits. On the other hand, the supervision of global banks from the ECB should have a more diluted cultural impact (than National Central Banks) as the regulator is now less related to a specific country's culture. Second, global banks have a multi-national presence where both employees and customers have diverse cultural backgrounds. Hence the cultural impact on the level of bank deposits is expected to be diluted for global banks.

To test this conjecture, we split our sample into domestic and global banks (Edwards, 2012) using the list of global banks maintained by the Financial Stability Board (FSB). ${ }^{20}$ We then re-run the model in Equation (1) separately for the two subsamples. For brevity, we only report the coefficients of the national culture variables (Table 3).

Results in Table 3 show that all three national culture variables maintain both their statistical and economic significance for the sample of domestic banks. Specifically, Trust, Hierarchy and Individualism have coefficients of $0.133,-0.188$ and 0.150 , respectively, all statistically significant at the $1 \%$ level. However, results for global banks change, since Hierarchy does not seem to carry any statistical significance, while the association of Individualism and bank deposits is only statistically significant at the $10 \%$ level. These two coefficients seem to be consistent with our conjecture that the impact of national culture characteristics will be diluted as banks become more exposed to a diverse set of cultures and at the same time are monitored and regulated by a transnational authority.

Interestingly, the strong relation of Trust with bank deposits remains statistically significant (1\% level) for the sub-sample of global banks with a coefficient of 0.280 . This result

\footnotetext{
${ }^{20}$ In this paper, we use the list published in 2015: http://www.fsb.org/wp-content/uploads/2015-update-of-list-ofglobal-systemically-important-banks-G-SIBs.pdf
} 
shows that Trust maintains a pervasive and unparalleled association with bank deposits across cultures, as it is a major component in building lasting customer relationships and satisfaction (Dwayne et al. 2004; Morgan and Hunt, 1994).

In summary, the results of Table 3 indicate that stricter regulation and the multi-cultural nature of global banks suppress the impact that hierarchy and individualism have on bank deposits. On the other hand, trust remains a characteristic with solid, positive association with bank deposits for both local and global banks.

\subsubsection{Is Deposit Volatility important?}

Given the robust positive relation between trust and deposit levels, both for domestic and global banks, and motivated by the new NSFR regulation aiming at shielding deposit stability, we investigate the trust-deposit level relation further by conditioning it on deposit stability. This analysis should provide new insights on the way trust affects depositor behaviour. In particular, elevated deposit volatility (e.g., increased uncertainty) is expected to be frowned upon by bank depositors hence weakening the impact of trust on deposit levels. Thus, to strengthen our inferences regarding the association between trust and deposit levels, we investigate whether there is cross-sectional heterogeneity in banks operating in the same cultural environment (i.e., keeping trust constant) with respect to a factor decreasing the impact of trust on bank deposit levels, that is, deposit volatility. In order to focus on the potential impact elevated historical deposit volatility (over a five-year horizon) ${ }^{21}$ might have on the trustdeposit level relation, we include in Equation (1) the interaction term Trust*Deposit Volatility as well as the uninteracted Deposit Volatility.

\footnotetext{
${ }^{21}$ The lag in measuring Deposit Volatility addresses potential feedback effects between deposit levels and volatility. Also, we note that the correlation between Trust and Deposit Volatility is virtually zero (i.e., correlation coefficient of 0.022 with a p-value of 0.43 ), thus addressing a potential criticism that Trust may be related to Deposit Volatility.
} 
Regression results are shown in Table 4. In column 1, we observe that the three main cultural variables remain statistically significant (at the $1 \%$ level). Their coefficients also have the same sign as the respective coefficients in Table 2, albeit with different sizes. However, the coefficients for the interaction term Trust*Deposit Volatility are negative and significant across all models consistent with the notion that deposit volatility weakens the impact of trust on deposit levels. Furthermore, the size of the coefficients indicates that for significant levels of deposit volatility, the impact of Trust on deposit levels completely disappears or might even reverse.

Next, we re-run Equation (1) on the sub-samples of domestic vs. global banks following the analysis of Table 3 (results reported in the $2^{\text {nd }}$ and $3^{\text {rd }}$ columns of Table 4 , respectively). We find similar results as before: most of the results seem to be concentrated in the sample of domestic instead of global banks. This trend is consistent with the explanation of a dilution in the effect of cultural characteristics in the case of more nationally diverse banks (i.e., global banks). Specifically, the coefficients for Individualism and Hierarchy are (not) significant for domestic (global) banks.

On the other hand, Trust appears to obtain robust positive coefficients across both subsamples, but more interestingly, this effect is largely reduced when combined with high deposit volatility (i.e., the interaction term) for both domestic and global banks.

In summary, the results in Table 4 are informative with respect to the impact that culture but also deposit volatility have on bank deposit levels. While the association of Individualism and Hierarchy are opposite (as expected) on bank deposit levels (negative and positive respectively), and their effect is only present in banks with more culturally homogeneous environments (i.e., domestic banks), the universal positive relation of Trust with bank deposit levels also remains across more culturally heterogeneous banks (i.e., global banks). More 
interestingly, this positive relation seems to be largely weakened in banks operating in an environment with the same level of trust but experiencing elevated deposit volatility. Furthermore, this result is larger in economic terms for global banks than domestic banks.

\section{Robustness checks}

We conduct a series of robustness checks for our analysis. First, we use an alternative measure of deposit levels. Next, we use alternative measures for the major independent variables (i.e., the three cultural characteristics). Finally, we address endogeneity concerns by conducting two stage least squares regressions (2SLS). The three robustness checks are described in sections 5.1, 5.2 and 5.3, respectively.

\subsection{Alternative dependent variable}

We use the logarithmic transformation of customer deposit balances as an alternative proxy for bank deposits. Our findings remain similar (Table 5). Specifically, when the entire sample of banks is used ( $1^{\text {st }}$ column) we obtain a positive and significant coefficient for both Trust and Hierarchy, and a negative coefficient for Individualism (all of them statistically significant at the $1 \%$ level). Next, when only the domestic banks are used in the analysis ( $2^{\text {nd }}$ column), all three coefficients remain the same in both the sign and statistical significance. Finally, in the sub-sample with global banks ( $3^{\text {rd }}$ column) only the trust variable remains positive and statistically signigicant (at the $1 \%$ level) consistent with the result of the trust variable in Table 3.

In short, Table 5 echoes the main finding of our paper that culture affects bank deposits, but less so in the case of global banks which have culturally more diverse customers and 
managers. On the other hand, trust appears to have a lasting impact on bank deposits that is robust across cultural borders.

\subsection{Alternative culture proxies}

We next conduct a robustness check on the main independent variables we use to explain bank deposit levels. One may claim reverse causality might be affecting the results (i.e., that the level of deposits influences cultural variables) since the cultural proxies from the WVS study are time variant. We, therefore, test our hypotheses using the Hofstede (1980) scores on national culture which remain static in the time-series. We follow Chen et al. (2015) and use Individualism and Uncertainty Avoidance as our alternative independent variables.

Individualism is defined as the social framework in which individuals take care of themselves and their immediate families. Individualistic bank managers are overconfident about the bank's ability to draw funding and may opt for the wholesale funding source instead of accumulating deposits from customers. ${ }^{22}$ Furthermore, individualistic bank customers are expected to overestimate their control over future financial conditions, thus saving less (consuming more) today. Hence, similar to our second hypothesis, we expect a negative relation between bank deposits and Hofstede (1980)’s individualism measure.

Uncertainty Avoidance is the degree to which members of a society feel comfortable with uncertainty and ambiguity. Consumers who tend to avoid uncertainty are more likely to prepare for the future thus they tend to save more today. Moreover, bank managers who tend to avoid uncertainty are more likely to follow a more prudent funding strategy by relying more on building customer relationships, hence more funding from deposits.

\footnotetext{
${ }^{22}$ At least one advantage of using wholesale sources over consumers' deposits for funding is that they are faster.
} 
Results of our regressions using Hofstede’s (1980) measures are reported in Table 6. We obtain similar results to Table 3 . Specifically, running the analysis on the entire sample $\left(1^{\text {st }}\right.$ column) a positive (negative) coefficient is obtained for Uncertainty Avoidance (Individualism). Both coefficients are statistically significant at the $1 \%$ level. When we conduct the analysis on the sub-sample of domestic banks ( $2^{\text {nd }}$ column) almost identical results are obtained for the two cultural variables. Finally, similar to prior results, no statistically significant results are present for the subsample of global banks, lending support to our conjecture of a diluted cultural impact in banks with more culturally diverse management and customer base.

\subsection{Endogeneity}

To address potential endogeneity concerns affecting our regression results (e.g., omitted variable bias), and to strengthen our case for a causal relationship between national culture variables and deposit levels, we re-estimate our model in Table 2 using a 2SLS regression model instead. To do this, we search for instrumental variables (IVs) that will correlate with the three national culture variables, but not the error term of the second stage regressions.

We inform our choice of IVs from the extant literature. As we have three variables to instrument (Individualism, Trust, Hierarchy), we use four instruments. We follow Li et al. (2013) for our first three IVs, using the Alesina et al. (2003) fractionalization variables Religion, Ethnicity and Language. The fourth IV is Geography ${ }^{23}$ following Kwok and Solomon (2006).

\footnotetext{
${ }^{23}$ The variable 'Geography' is an indicator variable for Africa, America, Asia, and Europe that takes the value 1 if a country is located geographically, not politically or economically, in one of the aforementioned continents and 0 otherwise. Out of 1308 observations, 321 are zeros and the rest are ones. Countries such as Sweden, Poland, Denmark, UK take the value 0, as they are not geographically located in any of the four continents.
} 
We include all the independent variables from Equation (1) as defined in the Data Appendix. We then follow the Baum et al. (2011) redundancy tests to verify whether any of these instruments should be dropped from our models. The null hypothesis of this test is that the "Instrument is redundant". Hence rejecting this hypothesis for each instrument, allows us to finalize the list of IVs to be used in our model. Each instrument passes the Baum et al. (2011) redundancy test (Table 7, Panel A) and the Anderson under-identification test is rejected, thus not invalidating our instrumental variable selection (Table 7, Panel B).

To test that the instruments for the cultural variables are valid, we compute the overidentifying restrictions test (Hansen J-statistic) for which the joint null hypothesis that the instruments are uncorrelated with the error term and correctly excluded from the second stage regression is not rejected (Table 7, Panel B).

Focusing on the key results, we observe that all national culture variables remain statistically significant (at the 1\% level) and with the same sign as in Table 2. Our results do not appear to be driven by omitted variable bias, therefore strengthening our argument for a causal link between the national culture attributes and the level of deposits.

\section{Conclusion}

This paper investigates whether national culture influences the levels of bank deposits in Europe. We use data for 99 European banks selected by EBA for the 2014 stress tests over the twenty-one-year period from 1995 to 2015. Our results show that banks in countries with high trust and hierarchy scores have higher levels of deposits as opposed to banks in countries with high individualism which have lower levels of deposits. Findings remain robust after using an alternative dependent variable as well as different cultural measures. 
Further, we find that the influence of individualism and hierarchy is more profound for domestic banks compared to global banks. This is intuitive since global banks have a presence in many countries, therefore, have employees and customers with diverse cultures. Thus, global banks operate in a less culturally homogeneous environment. At the same time, they operate under a stricter regulatory framework compared to domestic banks and are under the direct supervision of the European Central Bank (ECB). Domestic banks operate mainly in their local market, both their employees and customers are more culturally homogeneous and are supervised by the Central Bank of their country.

We analyze the universal positive relationship of trust on bank deposits further. We find that this relationship is significantly reduced for banks with elevated, historical volatility in bank deposits. Furthermore, this effect is larger for global than domestic banks.

We next offer evidence consistent with a causal relationship between cultural characteristics and bank deposit levels, using instrumental variables in a two-stage least squares framework. We find that the positive relationships of trust and hierarchy, and the negative relationship of individualism, on deposit levels are confirmed. We further note that the positive, causal relationship from trust on deposit levels is present for both global and domestic banks, supporting the popular view that banking is based on trust.

Our research is of interest to bank managers when deciding upon their liquidity sources as well as depositors when deciding whether to consume or save. Culture is an informal trait deeply embedded in societies and we aim to creating awareness to both bank managers and customers that their financial decisions are influenced by their culture.

Our findings are also of interest to bank supervisory authorities who strive to create a single banking rule book. Heavy regulation does not necessarily ensure uniformity in its application. In addition to enforcing a single rule book, authorities need to make its 
implementation and enforcement less prone to cultural variation. Given our reported differential effect of culture on domestic and global banks a possible way of mitigating cultural effects could be to reduce the differences between global and domestic banks, for example by encouraging diversity in employees and customers, but also in regulation, for example, direct ECB involvement with local - large - banks, similar to the ones included in the EBA stress tests. 


\section{References}

Acharya, V., Drechsler, I. \& Schnabl, P. 2014. A pyrrhic victory? Bank bailouts and sovereign credit risk. The Journal of Finance, 69, 2689-2739.

Acharya, V. \& Naqvi, H. 2012. The seeds of a crisis: A theory of bank liquidity and risk taking over the business cycle. Journal of Financial Economics, 106, 349-366.

Acharya, V. V. \& Steffen, S. 2015. The "greatest" carry trade ever? Understanding eurozone bank risks. Journal of Financial Economics, 115, 215-236.

Aggarwal, R., \& Goodell, J. W. 2009. Markets and institutions in financial intermediation: National characteristics as determinants. Journal of Banking \& Finance, 33(10), 17701780.

Ahern, K. R., Daminelli, D. \& Fracassi, C. 2015. Lost in translation? The effect of cultural values on mergers around the world. Journal of Financial Economics, 117, 165-189.

Alesina, A., Devleeschauwer, A., Easterly, W., Kurlat, S. \& Wacziarg, R. 2003. Fractionalization. Journal of Economic Growth, 8, 155-194.

Allen, D. E. \& Parwada, J. T. 2004. Effects of bank funds management activities on the disintermediation of bank deposits. Journal of Business Finance \& Accounting, 31, 1151-1170.

Allen, F., Carletti, E. \& Marquez, R. 2015. Deposits and bank capital structure. Journal of Financial Economics, 118, 601-619.

Allen, F. \& Santomero, A. M. 2001. What do financial intermediaries do? Journal of Banking \& Finance, 25, 271-294.

Anginer, D., Demirguc-Kunt, A. \& Zhu, M. 2014. How does deposit insurance affect bank risk? Evidence from the recent crisis. Journal of Banking \& Finance, 48, 312-321.

Barth, J. R., Caprio, G., Jr. \& Levine, R. 2013. Bank regulation and supervision in 180 countries from 1999 to 2011. Journal of Financial Economic Policy, 5, 111-219.

Baum, C. F., Schaffer, M. E. \& Stillman, S. 2011. Ivreg28: Stata module for extended instrumental variables/2sls and gmm estimation (v8). Statistical Software Components.

Beck, T., Demirgüç-Kunt, A. \& Levine, R. 2000. A new database on the structure and development of the financial sector. The World Bank Economic Review, 14, 597-605.

Beck, T. \& Levine, R. 2004. Stock markets, banks, and growth: Panel evidence. Journal of Banking \& Finance, 28, 423-442.

Berger, A. N. \& Hannan, T. H. 1989. The price-concentration relationship in banking. The Review of Economics and Statistics, 71, 291-299.

Biasutti, R. 1954. Razze e popoli della terra-iii. Africa-Unione Tipografico.

Boyd, J. H. \& De Nicollo, G. 2005. The theory of bank risk taking and competition revisited. Journal of Finance, 60, 1329-1343.

Brett, J., Adair, W., Lempereur, A., Okumura, T., Shikhirev, P., Tinsley, C. \& Lytle, A. 1998. Culture and joint gains in negotiation. Negotiation Journal, 14, 61-86.

Breuer, W., Riesener, M. \& Salzmann, A. J. 2012. Risk aversion vs. Individualism: What drives risk taking in household finance? The European Journal of Finance, 20, 446-462.

Calem, P. S. \& Carlino, G. A. 1991. The concentration / conduct relationship in bank deposit markets. The Review of Economics and Statistics, 73, 268-276.

Chen, Y., Dou, P. Y., Rhee, S. G., Truong, C. \& Veeraraghavan, M. 2015. National culture and corporate cash holdings around the world. Journal of Banking \& Finance, 50, 1-18.

Chui, A. C. W., Titman, S. \& Wei, K. C. J. 2010. Individualism and momentum around the world. The Journal of Finance, 65, 361-392.

Craig, B. R. \& Dinger, V. 2013. Deposit market competition, wholesale funding, and bank risk. Journal of Banking \& Finance, 37, 3605-3622. 
Demirgüç-Kunt, A. \& Huizinga, H. 2010. Bank activity and funding strategies: The impact on risk and returns. Journal of Financial Economics, 98, 626-650.

Diamond, D. W. \& Rajan, R. G. 2000. A theory of bank capital. The Journal of Finance, 55, 2431-2465.

Dolan, M. 2008. London benchmark rate under suspicion International Herald Tribune.

Dothan, U. \& Williams, J. 1980. Banks, bankruptcy, and public regulation. Journal of Banking \& Finance, 4, 65-87.

Dwayne, B., Pedro Simões, C. \& Alexandra, M. 2004. The role of communication and trust in explaining customer loyalty: An extension to the ecsi model. European Journal of Marketing, 38, 1272-1293.

Edwards, J. M. 2012. A model law framework for the resolution of g-sifis. Capital Markets Law Journal, 7, 122-150.

Fiordelisi, F., Marques-Ibanez, D. \& Molyneux, P. 2011. Efficiency and risk in european banking. Journal of Banking \& Finance, 35, 1315-1326.

Fischer, R. \& Chalmers, A. 2008. Is optimism universal? A meta-analytical investigation of optimism levels across 22 nations. Personality and Individual Differences, 45, 378-382.

Fiske, A. P. 1991. Structures of social life: The four elementary forms of human relations: Communal sharing, authority ranking, equality matching, market pricing, New York, NY, US, Free Press.

Freytag, A. \& Voll, S. 2013. Institutions and savings in developing and emerging economies. Public Choice, 157, 475-509.

Fukuyama, F. 1995. Trust : The social virtues and the creation of prosperity, London, London : Hamish Hamilton.

García-Kuhnert, Y., Marchica, M.-T. \& Mura, R. 2015. Shareholder diversification and bank risk-taking. Journal of Financial Intermediation.

Geoffrey, T. W. \& Kamel, M. 2004. Hrm in malaysia. Managing human resources in asiapacific. Routledge.

Giannetti, M. \& Yafeh, Y. 2011. Do cultural differences between contracting parties matter? Evidence from syndicated bank loans. Management Science, 58, 365-383.

Glaeser, E. L., Laibson, D. I., Scheinkman, J. A. \& Soutter, C. L. 2000. Measuring trust. Quarterly Journal of Economics, 115, 811-846.

Goldstein, H. 2011. Multilevel statistical models, John Wiley \& Sons.

Goldstein, I. \& Pauzner, A. D. Y. 2005. Demand-deposit contracts and the probability of bank runs. Journal of Finance, 60, 1293-1327.

Guiso, L., Sapienza, P. \& Zingales, L. 2006. Does culture affect economic outcomes? Journal of Economic Perspectives, 20, 23-48.

Guiso, L., Sapienza, P. \& Zingales, L. 2008. Trusting the stock market. Journal of Finance, 63, 2557-2600.

Harker P. T., Zenios S. A. 2000. Performance of Financial Institutions: Efficiency, Innovation, Regulation. Cambridge University Press, New York.

Hofmann, B. \& Mizen, P. 2004. Interest rate pass-through and monetary transmission: Evidence from individual financial institutions' retail rates. Economica, 71, 99-123.

Hofstede, G. H. 1980. Culture's consequences : International differences in work-related values. Sage, Beverly Hills, CA.

Hofstede, G. H. 2001. Culture's consequences : Comparing values, behaviors, institutions, and organizations across nations. Sage Publications, Thousand Oaks, CA.

Huang, R. \& Ratnovski, L. 2011. The dark side of bank wholesale funding. Journal of Financial Intermediation, 20, 248-263. 
Hutchison, D. E. 1995. Retail bank deposit pricing: An intertemporal asset pricing approach. Journal of Money, Credit and Banking, 27, 217-231.

Iyer, R. \& Puri, M. 2012. Understanding bank runs: The importance of depositor-bank relationships and networks. American Economic Review, 102, 1414-45.

Jin, Y. \& Zeng, Z. 2014. Banking risk and macroeconomic fluctuations. Journal of Banking \& Finance, 48, 350-360.

Kanagaretnam, K., Lim, C. Y. \& Lobo, G. J. 2011. Effects of national culture on earnings quality of banks. Journal of International Business Studies, 42, 853-874.

Kanagaretnam, K., Chee Yeow, L. \& Lobo, G. J. 2014. Influence of national culture on accounting conservatism and risk-taking in the banking industry. Accounting Review, 89, 1115-1149.

Keeley, M. C. \& Furlong, F. T. 1990. A reexamination of mean-variance analysis of bank capital regulation. Journal of Banking \& Finance, 14, 69-84.

Kiser, E. K. 2004. Modeling the whole firm: The effect of multiple inputs and financial intermediation on bank deposit rates. St. Louis: Federal Reserve Bank of St Louis.

Kiss, H. J., Rodriguez-Lara, I. \& Rosa-García, A. 2014. Do social networks prevent or promote bank runs? Journal of Economic Behavior \& Organization, 101, 87-99.

Kwok, C. C. Y. \& Solomon, T. 2006. National culture and financial systems. Journal of International Business Studies, 37, 227-247.

La Porta, R., Florencio, L.-d.-S., Shleifer, A. \& Vishny, R. W. 1997. Trust in large organizations. The American Economic Review, 87, 333-338.

La Porta, R., Lopez-de-Silanes, F., Shleifer, A. \& Vishny, R. W. 1998. Law and finance. Journal of Political Economy, 106, 1113.

Laeven, L., Ratnovski, L. \& Tong, H. 2014. Bank size and systemic risk. IMF Staff Discussion Note 14/04.

Laeven, L., Ratnovski, L. \& Tong, H. 2016. Bank size, capital, and systemic risk: Some international evidence. Journal of Banking \& Finance, 69, S25-S34.

Lambert, C., Noth, F. \& Schüwer, U. 2017. How do insured deposits affect bank risk? Evidence from the 2008 emergency economic stabilization act. Journal of Financial Intermediation, 29, 81-102.

Levine, R. \& Zervos, S. 1998. Stock markets, banks, and economic growth. The American Economic Review, 88, 537-558.

Li, K., Griffin, D., Yue, H. \& Zhao, L. 2013. How does culture influence corporate risk-taking? Journal of Corporate Finance, 23, 1-22.

Lyons, B. \& Mehta, J. 1997. Contracts, opportunism and trust: Self-interest and social orientation. Cambridge Journal of Economics, 21, 239-257.

Manos, R., Drori, I., Shoham, A. \& Aharonson, B. S. 2015. National culture and national savings: Is there a link? International Review of Applied Economics, 29, 455-481.

Mester, L. J. 1987. A multiproduct cost study of savings and loans. The Journal of Finance, 42, 423-445.

Michaelides, A. 2014. Cyprus: From boom to bail-in. Economic Policy, 29, 639-689.

Michaud, F. \& Upper, C. 2008. What drives interbank rates? Evidence from the libor panel. BIS Quarterly Review, 47-58.

Morgan, R. M. \& Hunt, S. D. 1994. The commitment-trust theory of relationship marketing. Journal of Marketing, 58, 20-38.

Mourouzidou-Damtsa, S., Milidonis, A. \& Stathopoulos, K. 2017. National culture and bank risk-taking. Journal of Financial Stability. 
Porta, R. L., Lopez-De-Silanes, F., Shleifer, A. \& Vishny, R. W. 1997. Legal determinants of external finance. The Journal of Finance, 52, 1131-1150.

Putnam, R. D. 2000. Bowling alone: The collapse and revival of american community, New York, Simon \& Schuster.

Raudenbush, S. W. \& Bryk, A. S. 2002. Hierarchical linear models: Applications and data analysis methods, Sage.

Sandmo, A. 1970. The effect of uncertainty on saving decisions. The Review of Economic Studies, 37, 353-360.

Sapienza, P., Toldra-Simats, A. \& Zingales, L. 2013. Understanding trust. Economic Journal, 123, 1313-1332.

Sapienza, P. \& Zingales, L. 2012. A trust crisis. International Review of Finance, 12, 123-131.

Schlueter, T., Sievers, S. \& Hartmann-Wendels, T. 2015. Bank funding stability, pricing strategies and the guidance of depositors. Journal of Banking \& Finance, 51, 43-61.

Schumpeter 1961. The theory of economic development.

Schwartz, S. H. 1994. Beyond individualism/collectivism: New cultural dimensions of values. In: KIM, U., TRIANDIS, H. C., Ç, K., CHOI, S. C. \& YOON, G. (eds.) Individualism and collectivism: Theory, method, and applications. Thousand Oaks, CA, US: Sage Publications, Inc.

Thakor, A., 2016. Corporate culture in banking. Economic Policy Review 22, 5-16.

Trompenaars, A. 2012. Riding the waves of culture : Understanding diversity in global business, London, London : Nicholas Brealey.

Van den Steen, E. 2004. Rational overoptimism (and other biases). American Economic Review, 94, 1141-1151.

Van Hoorn, A. 2014. Individualism and the cultural roots of management practices. Journal of Economic Behavior \& Organization, 99, 53-68. 


\section{Data Appendix}

Description of data variables and sources

\begin{tabular}{|c|c|c|}
\hline Variable names & Variable definition & Data from \\
\hline \multicolumn{3}{|c|}{ Bank deposit level variables } \\
\hline Deposit level & $\begin{array}{l}\text { Customer deposits scaled by the } \\
\text { bank's total assets. }\end{array}$ & Bloomberg \\
\hline Deposit level (Log) & $\begin{array}{l}\text { The logarithmic transformation } \\
\text { of the customer deposits. }\end{array}$ & Bloomberg \\
\hline \multicolumn{3}{|l|}{ Culture variables } \\
\hline Trust & $\begin{array}{l}\text { Trust is measured based on } \\
\text { survey responses as to whether } \\
\text { or not most people can be } \\
\text { trusted. Consistent with Ahern et } \\
\text { al. (2015) we track the responses } \\
\text { to the following survey question: } \\
\text { "Generally speaking, would you } \\
\text { say that most people can be } \\
\text { trusted or that you need to be } \\
\text { very careful in dealing with } \\
\text { people?" } \\
\text { Higher values indicate higher } \\
\text { trust in people. The variable } \\
\text { takes values between zero and } \\
\text { one. }\end{array}$ & World Values Survey (WVS) ${ }^{24}$ \\
\hline Individualism & $\begin{array}{l}\text { Individualism is measured based } \\
\text { on survey responses to whether } \\
\text { 'incomes should be made more } \\
\text { equal or that there should be } \\
\text { more incentives for individual } \\
\text { effort. Consistent with Ahern et } \\
\text { al. (2015) we track the responses } \\
\text { to the following survey question: } \\
\text { "How would you place your } \\
\text { views on this scale? } 1 \text { means you } \\
\text { completely agree with the } \\
\text { statement on the left; } 10 \text { means } \\
\text { you agree completely with the } \\
\text { statement on the right; and if } \\
\text { your views fall somewhere in } \\
\text { between, you can choose any } \\
\text { number in between: } \\
\text { Incomes should be made more } \\
\text { equal-We need larger income } \\
\text { differences as incentives for } \\
\text { individual effort." } \\
\text { Higher values indicate more } \\
\text { individualism. We re-scale the }\end{array}$ & World Values Survey (WVS) \\
\hline
\end{tabular}

${ }^{24}$ http://www.worldvaluessurvey.org/WVSContents.jsp 


\begin{tabular}{|c|c|c|}
\hline Variable names & Variable definition & Data from \\
\hline & $\begin{array}{l}\text { variable so that it takes values } \\
\text { between zero and one. }\end{array}$ & \\
\hline Hierarchy & $\begin{array}{l}\text { Hierarchy is measured based on } \\
\text { survey responses as to whether } \\
\text { or not one follows instructions at } \\
\text { work or has to be convinced } \\
\text { first. Consistent with Ahern et } \\
\text { al. (2015) we track the responses } \\
\text { to the following survey question: } \\
\text { "People have different ideas } \\
\text { about following instructions at } \\
\text { work. Some say that one should } \\
\text { follow one's superior's } \\
\text { instructions even when one does } \\
\text { not fully agree with them. Others } \\
\text { say that one should follow one's } \\
\text { superior's instructions only } \\
\text { when one is convinced that they } \\
\text { are right. With which of these } \\
\text { two options do you agree? } 1 \text {. } \\
\text { Should follow instructions; } 2 \text {. } \\
\text { Must be convinced first." } \\
\text { Higher values indicate higher } \\
\text { hierarchy, i.e., that people are } \\
\text { happy to follow instructions } \\
\text { without being convinced first. } \\
\text { The variable takes values } \\
\text { between zero and one. }\end{array}$ & World Values Survey (WVS) \\
\hline
\end{tabular}

\section{Deposit Stability Variables}

\begin{tabular}{|c|c|c|}
\hline Deposit Volatility & $\begin{array}{l}\text { Volatility of deposits is defined } \\
\text { as the standard deviation of the } \\
\text { customer deposits over the past } \\
\text { five years. Volatility of deposits } \\
\text { at time } t \text { is estimated using the } \\
\text { customer deposit levels from } t-4 \\
\text { to } t \text {. }\end{array}$ & Bloomberg \\
\hline Trust*Volatility & $\begin{array}{l}\text { The interaction of Trust with } \\
\text { Volatility of deposits (as defined } \\
\text { above). }\end{array}$ & WVS and Bloomberg \\
\hline \multicolumn{3}{|l|}{ Control Variables: } \\
\hline \multicolumn{3}{|c|}{ - Bank Financial Variables } \\
\hline Risk & $\begin{array}{l}\text { ROA volatility is defined as the } \\
\text { standard deviation of the ratio of } \\
\text { gross pre-tax profit (including } \\
\text { loan loss provisions) to total } \\
\text { assets over five years, that is, } \\
\text { ROA Volatility at time } t \text { is }\end{array}$ & Bloomberg \\
\hline
\end{tabular}




\begin{tabular}{|c|c|c|}
\hline Variable names & Variable definition & Data from \\
\hline & $\begin{array}{l}\text { estimated using the ROA values } \\
\text { from } t-4 \text { to } t \text {. }\end{array}$ & \\
\hline Bank Size & $\begin{array}{l}\text { Bank Size is the logarithmic } \\
\text { transformation of the bank's } \\
\text { total assets. }\end{array}$ & Bloomberg \\
\hline Net Interest Margin & $\begin{array}{l}\text { Net Interest Margin is the ratio } \\
\text { (Interest Income - Interest } \\
\text { expense) / Interest income and } \\
\text { captures the interest rate } \\
\text { differences between banks. }\end{array}$ & Bloomberg \\
\hline Leverage & $\begin{array}{l}\text { Leverage is defined as the ratio } \\
\text { Total Equity / Total Assets. }\end{array}$ & Bloomberg \\
\hline Interest Activity & $\begin{array}{l}\text { Interest Activity is defined as } \\
\text { the ratio Interest income / Total } \\
\text { operating income and measures } \\
\text { the percentage of the bank's } \\
\text { income originating from } \\
\text { traditional banking activities. }\end{array}$ & Bloomberg \\
\hline Loans to Assets & $\begin{array}{l}\text { Loans to Assets is defined as the } \\
\text { ratio of Total Loans / Total } \\
\text { Assets. }\end{array}$ & Bloomberg \\
\hline $\begin{array}{l}\text { 3-month } \\
\text { Euribor \% }\end{array}$ & $\begin{array}{l}\text { The historical close of the 3- } \\
\text { month Euribor. }\end{array}$ & $\begin{array}{r}\text { European Central Bank } \\
\text { Statistical Warehouse }\end{array}$ \\
\hline Wholesale Funding & $\begin{array}{l}\text { Wholesale Funding is the } \\
\text { amount of liquidity the bank } \\
\text { obtained from sources other than } \\
\text { customer deposits (including the } \\
\text { interbank market and } \\
\text { securitisation) scaled by the } \\
\text { bank's total assets. }\end{array}$ & Bloomberg \\
\hline \multicolumn{3}{|c|}{ - Country's Economic Performance Variables } \\
\hline Consumption \% GDP & $\begin{array}{l}\text { The country's total household } \\
\text { consumption expenditure as a \% } \\
\text { of the GDP. }\end{array}$ & World Bank Database \\
\hline Savings \% National Income & $\begin{array}{l}\text { The country's total gross savings } \\
\text { as a percentage of its gross } \\
\text { national income. }\end{array}$ & World Bank Database \\
\hline GDP growth & $\begin{array}{l}\text { The year-on-year GDP growth } \\
\text { of the country. }\end{array}$ & World Bank Database \\
\hline GDP per capita & $\begin{array}{l}\text { GDP per capita is measured as } \\
\text { the logarithm of the GDP per } \\
\text { capita. }\end{array}$ & World Bank Database \\
\hline Inflation & $\begin{array}{l}\text { The inflation percentage per } \\
\text { year per country. }\end{array}$ & World Bank Database \\
\hline
\end{tabular}




\begin{tabular}{llr} 
Variable names & Variable definition & Data from \\
\hline & $\begin{array}{l}\text { A categorical variable, taking } \\
\text { the values 1, 2, } 3 \text { or 4 }\end{array}$ & \\
representing the four legal & \\
origins English law (1), French & Law (2), German law (3), & \\
& Scandinavian law (4). &
\end{tabular}

\section{- Institutional Quality and governance variables}

\begin{tabular}{|c|c|c|}
\hline Creditor Rights & $\begin{array}{l}\text { A categorical variable taking the } \\
\text { values } 0,1,2,3 \text { or } 4 \text { aggregating } \\
\text { different creditor rights. The } \\
\text { index if formed by adding } 1 \\
\text { when the country imposes } \\
\text { restrictions, such as minimum } \\
\text { dividends to file for } \\
\text { reorganisation; } 2 \text { when secured } \\
\text { creditors are able to regain } \\
\text { position once their petition has } \\
\text { been approved; } 3 \text { secure } \\
\text { creditors rank first in the } \\
\text { liquidation process; } 4 \text { the debtor } \\
\text { does not retain the } \\
\text { administration of their assets } \\
\text { pending the resolution process. }\end{array}$ & La Porta et al., 1998 \\
\hline Rating on Accounting Standards & $\begin{array}{l}\text { An index measuring the quality } \\
\text { of the country's accounting } \\
\text { standards. To construct the } \\
\text { index, seven categories were } \\
\text { assessed: general information, } \\
\text { income statements, balance } \\
\text { sheets, fund flow statements, } \\
\text { accounting standards, stock data } \\
\text { and special items. }\end{array}$ & La Porta et al., 1998 \\
\hline Capital Stringency Index & $\begin{array}{l}\text { Capital Stringency Index is a } \\
\text { capital adequacy measure under } \\
\text { adverse conditions. }\end{array}$ & Barth et al., 2013 \\
\hline Listed & $\begin{array}{l}\text { A binary variable taking the } \\
\text { value of one if the bank is listed } \\
\text { on any stock exchange, zero } \\
\text { otherwise. }\end{array}$ & Bloomberg \\
\hline Domestic CEO & $\begin{array}{l}\text { A binary variable taking the } \\
\text { value } 0 \text { if the CEO is not a } \\
\text { national and the value } 1 \text { if the } \\
\text { CEO is a national of the bank's } \\
\text { headquartering country. }\end{array}$ & Boardex \\
\hline $\begin{array}{l}\text { Financial Statement } \\
\text { Transparency }\end{array}$ & $\begin{array}{l}\text { A measure of the transparency } \\
\text { of the bank financial statement } \\
\text { practices, with higher values } \\
\text { indicating more transparency. } \\
\text { The index takes values from } 0 \text { to } \\
6 \text {. }\end{array}$ & Barth et al., 2013 \\
\hline
\end{tabular}




\begin{tabular}{|c|c|c|}
\hline Variable names & Variable definition & Data from \\
\hline \multicolumn{3}{|l|}{ Instrumental Variables } \\
\hline Ethnical Fractionalisation & $\begin{array}{l}\text { The ethnical fractionalisation is } \\
\text { the probability that two } \\
\text { inidividuals, randomly selected } \\
\text { from a country's population, } \\
\text { belong to different ethnicities. }\end{array}$ & Alesina et al., 2003 \\
\hline Religion & $\begin{array}{l}\text { The percentage of the population } \\
\text { of each country that belonged to } \\
\text { the: (1) Roman Catholic; (2) } \\
\text { Protestant; and (3) Muslim } \\
\text { religions in the world in } 1980 .\end{array}$ & Alesina et al., 2003 \\
\hline Language & $\begin{array}{l}\text { A measure of the shares of } \\
\text { languages spoken as "mother } \\
\text { tongues", generally based on } \\
\text { national census data. }\end{array}$ & Alesina et al., 2003 \\
\hline Geography & $\begin{array}{l}\text { Indicator variables for Africa, } \\
\text { America, Asia, and Europe that } \\
\text { take the value of one if a country } \\
\text { is in one of the continents above, } \\
\text { and zero otherwise. }\end{array}$ & http://www.worldatlas.com/ \\
\hline
\end{tabular}

\section{Hofstede Cultural Values (used in robustness checks)}

$\begin{array}{ll} & \text { The high side of this dimension, } \\ & \text { called individualism, can be } \\ & \text { defined as a preference for a } \\ & \text { loosely-knit social framework in } \\ & \text { which individuals are expected } \\ \text { to take care of only themselves } \\ \text { and their immediate families. Its } \\ \text { opposite, collectivism, } \\ \text { represents a preference for a } \\ \text { tightly-knit framework in } \\ \text { society in which individuals can } \\ \text { expect their relatives or } \\ \text { members of a particular in-group } \\ \text { to look after them in exchange } \\ \text { for unquestioning loyalty. A } \\ \text { society's position on this } \\ \text { dimension is reflected in } \\ \text { whether people's self-image is } \\ \text { defined in terms of “I” or “we.” } \\ \text { The Uncertainty Avoidance } \\ \text { dimension expresses the degree } \\ \text { to which the members of a } \\ \text { society feel uncomfortable with } \\ \text { uncertainty and ambiguity. The } \\ \text { fundamental issue here is how a } \\ \text { society deals with the fact that } \\ \text { the future can never be known: }\end{array}$




\begin{tabular}{ll} 
Variable names & Variable definition \\
\hline should we try to control the \\
future or just let it happen? \\
Countries exhibiting strong UA \\
maintain rigid codes of belief \\
and behaviour and are intolerant \\
of unorthodox behaviour and \\
ideas. Weak UA societies \\
maintain a more relaxed attitude \\
in which practice counts more \\
than principles
\end{tabular}




\section{Figures}

Figure 1 - Average Cultural Values by country: The average scores for each cultural value (trust, hierarchy and individualism) by country. The $\mathrm{x}$-axis comprises the alphabetical listing of countries, evenly spaced out.

Panel A: Trust

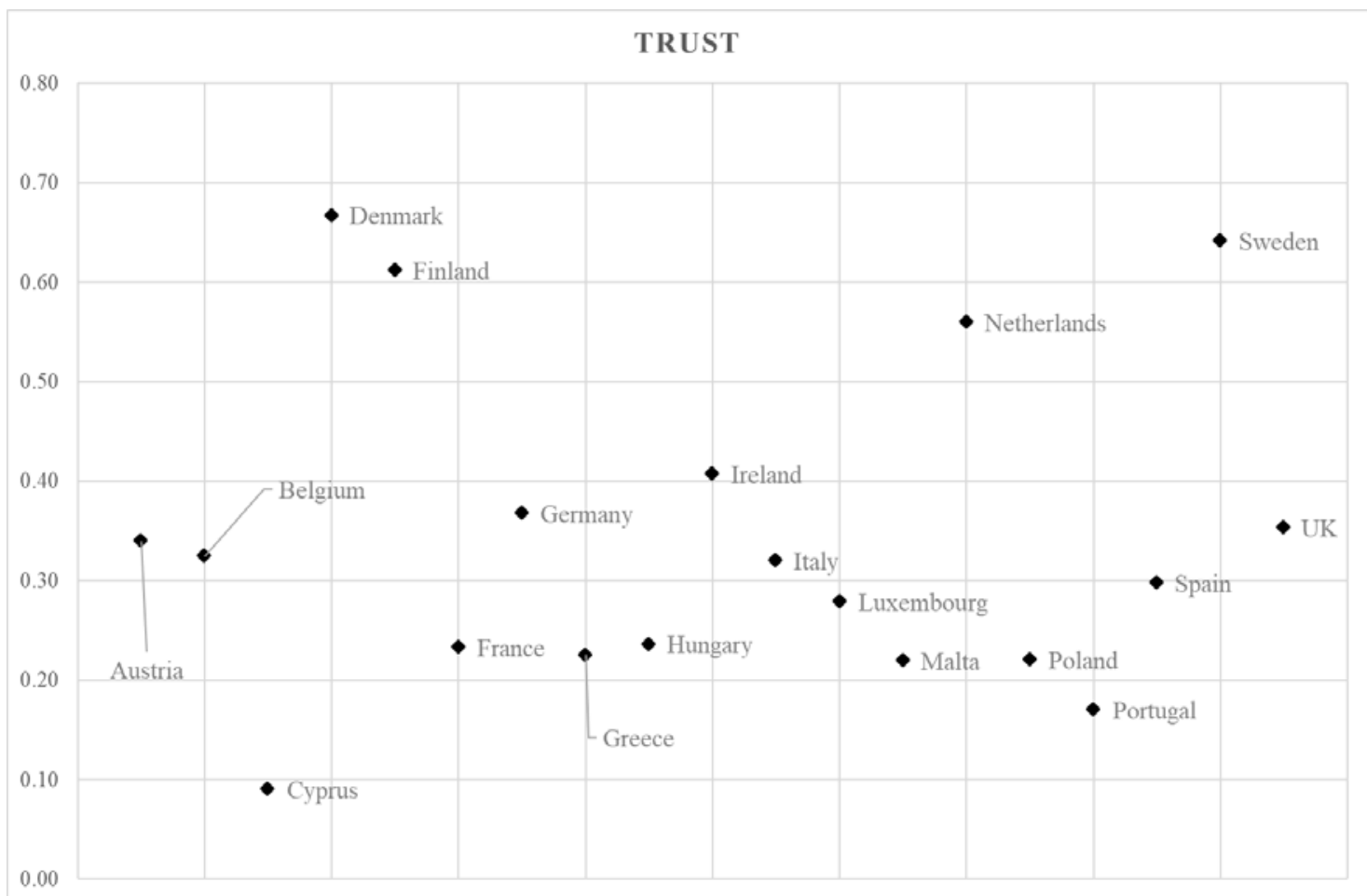

Panel B: Hierarchy

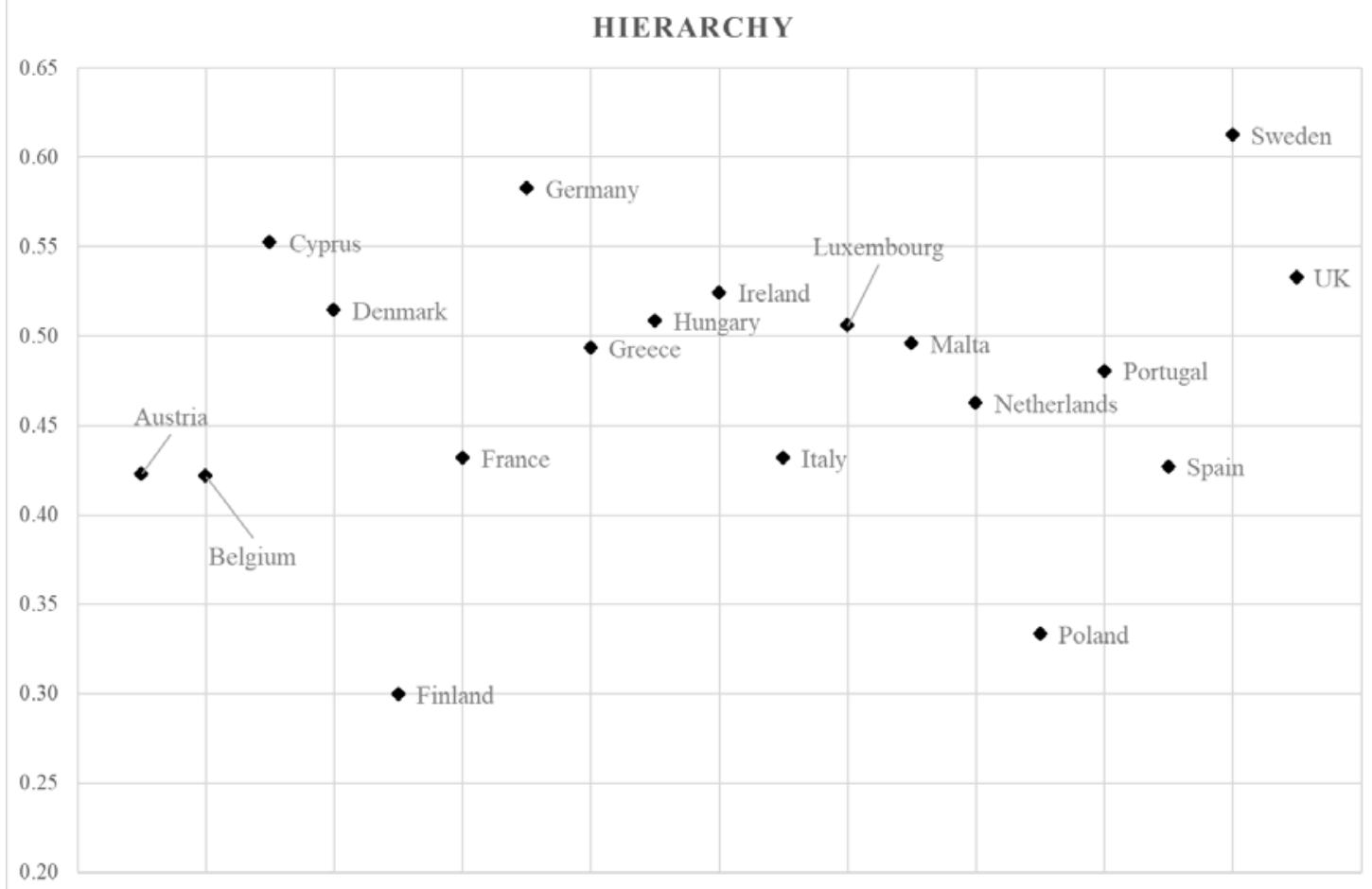


Panel C: Individualism

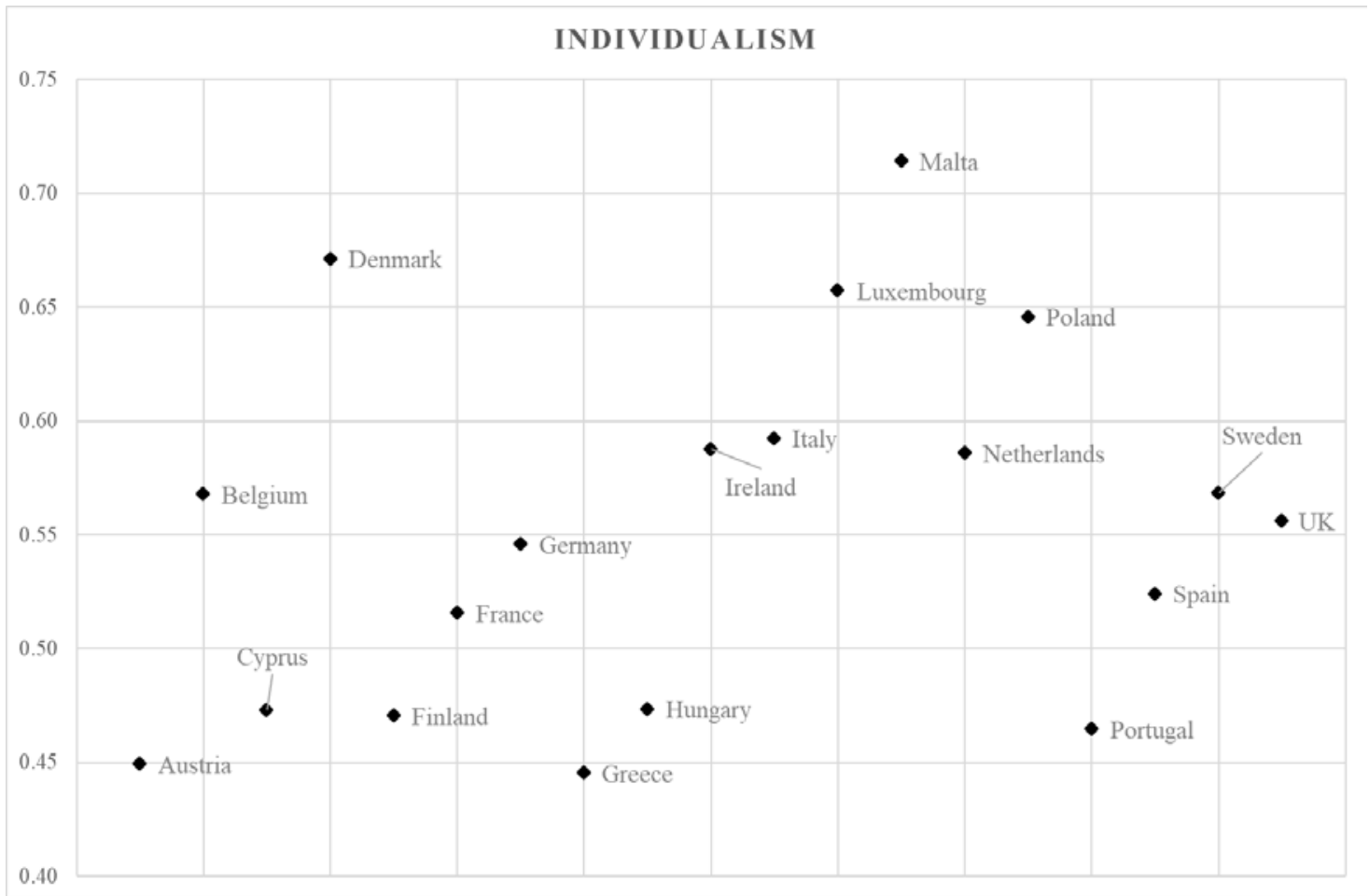


Figure 2 - Average deposits scaled by total assets by country

Figure 2 presents the average customer deposits scaled by total assets by country. The Data Appendix provides the variable definitions and data sources.

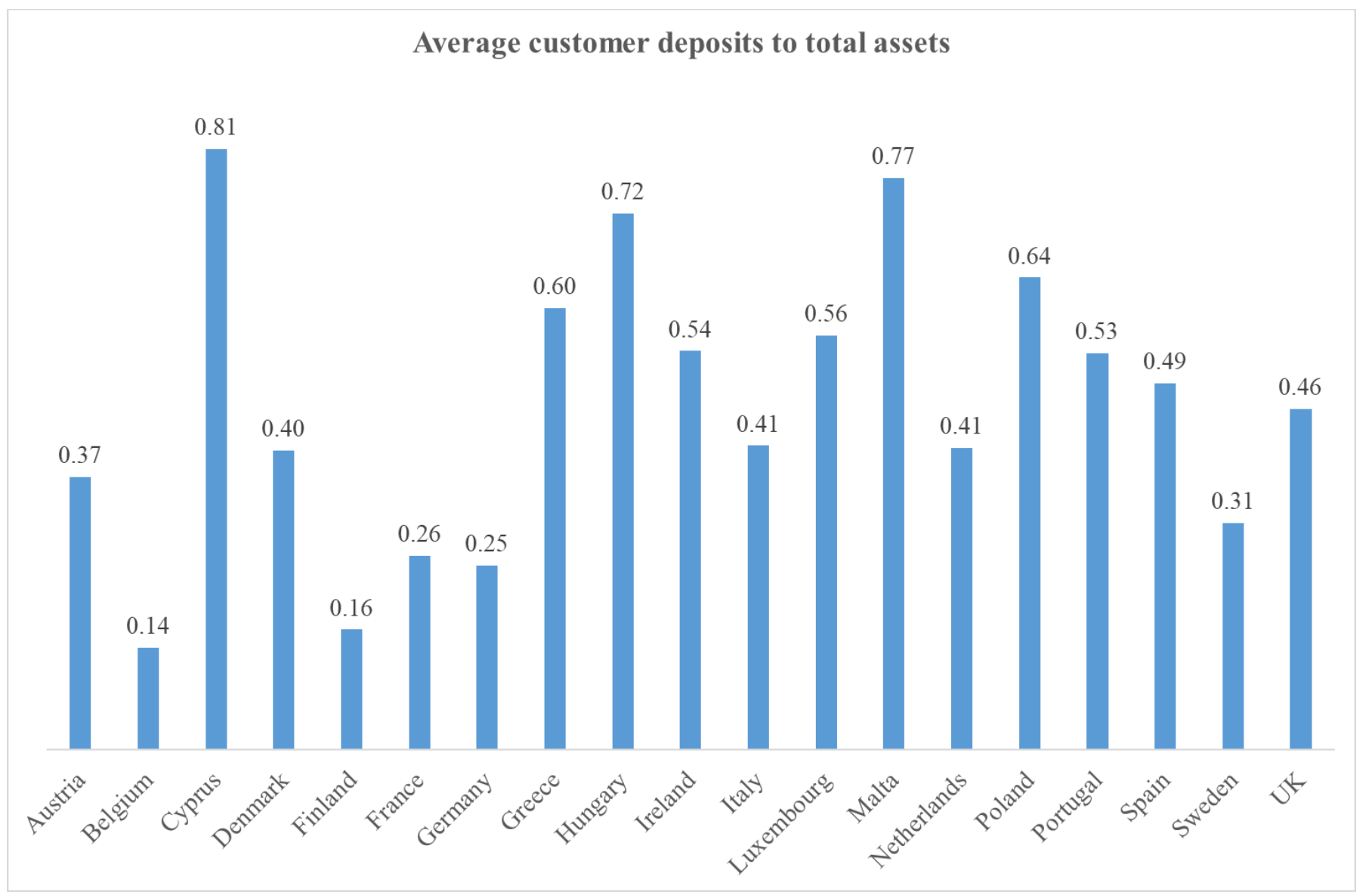




\section{Tables}

Table 1 - Descriptive Statistics

Descriptive statistics are provided for all variables. The Data Appendix includes definitions.

\begin{tabular}{|c|c|c|c|c|c|}
\hline Variable / Statistic & Mean & Median & $\begin{array}{l}\text { Standard } \\
\text { Deviation }\end{array}$ & $\begin{array}{r}\text { 25th } \\
\text { percentile } \\
\end{array}$ & $\begin{array}{r}75 \text { th } \\
\text { percentile } \\
\end{array}$ \\
\hline \multicolumn{6}{|l|}{ Dependent Variables } \\
\hline $\begin{array}{l}\text { Customer Deposits to Total } \\
\text { Assets }\end{array}$ & 0.409 & 0.406 & 0.206 & 0.260 & 0.543 \\
\hline Customer Deposits (Log) & 10.174 & 10.202 & 1.671 & 9.080 & 11.262 \\
\hline \multicolumn{6}{|l|}{ National Culture Variables } \\
\hline Trust & 0.354 & 0.311 & 0.145 & 0.267 & 0.417 \\
\hline Individualism & 0.534 & 0.548 & 0.084 & 0.476 & 0.592 \\
\hline Hierarchy & 0.485 & 0.468 & 0.080 & 0.414 & 0.548 \\
\hline \multicolumn{6}{|l|}{ Bank Financial Variables } \\
\hline Loans to Assets ratio & 0.532 & 0.565 & 0.206 & 0.425 & 0.671 \\
\hline Risk & 0.394 & 0.217 & 0.629 & 0.112 & 0.416 \\
\hline Size (Log) & 11.268 & 11.209 & 1.568 & 10.267 & 12.376 \\
\hline Net Interest Margin & 0.454 & 0.455 & 0.211 & 0.295 & 0.607 \\
\hline Leverage & 0.059 & 0.054 & 0.031 & 0.037 & 0.073 \\
\hline Interest Activity ratio & 6.838 & 4.893 & 8.501 & 2.898 & 9.278 \\
\hline Wholesale Funding & 0.527 & 0.519 & 0.212 & 0.384 & 0.686 \\
\hline \multicolumn{6}{|l|}{ Country Variables } \\
\hline Consumption & 0.567 & 0.571 & 0.064 & 0.537 & 0.610 \\
\hline Savings & 0.220 & 0.222 & 0.049 & 0.191 & 0.257 \\
\hline Legal Origin & 2.408 & 2.000 & 0.833 & 2.000 & 3.000 \\
\hline GDP growth & 0.016 & 0.017 & 0.026 & 0.004 & 0.033 \\
\hline Inflation & 0.022 & 0.020 & 0.022 & 0.012 & 0.027 \\
\hline GDP per capita (Log) & 10.313 & 10.438 & 0.518 & 10.068 & 10.659 \\
\hline \multicolumn{6}{|l|}{ Other Control Variables } \\
\hline Creditors Rights & 2.05 & 2.00 & 1.04 & 1.00 & 3.00 \\
\hline Capital Stringency Index & 4.522 & 5.000 & 1.693 & 3.000 & 6.000 \\
\hline Euribor 3-month average \% & 2.43 & 2.18 & 1.78 & 0.81 & 4.26 \\
\hline CEO nationality & 0.93 & 1.00 & 0.25 & 1.00 & 1.00 \\
\hline $\begin{array}{l}\text { Rating on Accounting } \\
\text { Standards }\end{array}$ & 61.85 & 62.00 & 10.69 & 61.00 & 64.00 \\
\hline $\begin{array}{l}\text { Financial Statement } \\
\text { Transparency Index }\end{array}$ & 5.04 & 5.00 & 0.76 & 5.00 & 6.00 \\
\hline Listed & 0.78 & 1.00 & 0.42 & 1.00 & 1.00 \\
\hline \multicolumn{6}{|l|}{ Interaction Variables } \\
\hline Trust*Deposit Volatility & 0.123 & 0.090 & 0.119 & 0.054 & 0.149 \\
\hline Deposit Volatility & 11.196 & 3.408 & 20.432 & 1.163 & 10.633 \\
\hline \multicolumn{6}{|l|}{ Hofstede Cultural variables } \\
\hline Individualism & 65.471 & 67.000 & 14.385 & 60.000 & 76.000 \\
\hline Uncertainty Avoidance & 69.834 & 75.000 & 21.774 & 65.000 & 86.000 \\
\hline
\end{tabular}


Table 2 - Multilevel regression results (all banks)

The dependent variable is the bank customer deposits scaled by the bank's total assets. The Data Appendix provides the variable definitions and data sources. Year fixed effects are also used. *, **, *** denotes statistical significance at the $10 \%, 5 \%$ and $1 \%$ levels respectively. The numbers in parentheses report the test statistic.

\begin{tabular}{|c|c|c|c|}
\hline \multirow{2}{*}{$\begin{array}{l}\text { Culture variables } \\
\text { Trust }\end{array}$} & 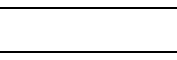 & \multicolumn{2}{|c|}{ Institutional Quality and Governance variables } \\
\hline & $\begin{array}{r}0.118^{* * *} \\
(2.50)\end{array}$ & Euribor 3 month & $\begin{array}{l}-0.004 \\
(-0.13)\end{array}$ \\
\hline Individualism & $\begin{array}{r}-0.120 * * * \\
(-3.02)\end{array}$ & Creditor Rights & $\begin{array}{r}0.020 * * \\
(1.97)\end{array}$ \\
\hline Hierarchy & $\begin{array}{r}0.177^{* * *} \\
(4.39) \\
\end{array}$ & Accounting Standards & $\begin{array}{l}-0.001 \\
(-0.70)\end{array}$ \\
\hline Bank Financial Variables & & Capital Stringency Index & $0.004^{* * *}$ \\
\hline Wholesale funding & $-0.282 * * *$ & & 017 017 \\
\hline Bank Size & $-0.012 * * *$ & & $(-1.25)$ \\
\hline Risk & $\begin{array}{r}(-2.98) \\
-0.011^{* * *} \\
(-3.74)\end{array}$ & $\begin{array}{l}\text { CEO nationality } \\
\text { Financial Statement }\end{array}$ & $\begin{array}{l}0.006 \\
(0.89)\end{array}$ \\
\hline & & Transparency & $0.011^{* * *}$ \\
\hline Net Interest Margin & $\begin{array}{r}0.018 \\
(1.58)\end{array}$ & Listed & $\begin{array}{r}(4.45) \\
0.053^{* * *}\end{array}$ \\
\hline Leverage & $-0.644 * * *$ & & $(2.87)$ \\
\hline Interest Activity & $\begin{array}{r}(-7.46) \\
0.001 \\
(1.48)\end{array}$ & $\begin{array}{l}\text { Constant } \\
\text { Number of observations }\end{array}$ & $\begin{array}{r}0.586^{* * *} \\
(3.43) \\
1,308\end{array}$ \\
\hline Loans to Assets & $\begin{array}{r}0.116^{* * *} \\
(7.64) \\
\end{array}$ & Adjusted R2 & 0.853 \\
\hline Country Variables & & & \\
\hline GDP growth & $\begin{array}{r}0.089 \\
(0.87)\end{array}$ & & \\
\hline GDP per capita & $\begin{array}{l}-0.021 \\
(-1.18)\end{array}$ & & \\
\hline Inflation & $\begin{array}{l}-0.182 \\
(-1.46)\end{array}$ & & \\
\hline Consumption & $\begin{array}{l}0.087 \\
(1.47)\end{array}$ & & \\
\hline Savings & $\begin{array}{l}-0.021 \\
(-1.55)\end{array}$ & & \\
\hline
\end{tabular}


Table 3 - Multilevel regression results (global versus domestic banks)

The dependent variable is the bank customer deposits scaled by the bank's total assets. The Data Appendix provides the variable definitions and data sources. Year fixed effects are also used. *, **, *** denote statistical significance at the $10 \%, 5 \%$ and $1 \%$ levels respectively. The numbers in parentheses report the test statistic.

\begin{tabular}{lrr}
\hline & $\begin{array}{r}\text { Domestic } \\
\text { Banks }\end{array}$ & $\begin{array}{r}\text { Global } \\
\text { Banks }\end{array}$ \\
\hline $\begin{array}{l}\text { Culture variables } \\
\text { Trust }\end{array}$ & $0.136^{* * *}$ & $0.280^{* * *}$ \\
$\quad$ Individualism & $(3.36)$ & $(2.12)$ \\
$\quad$ Hierarchy & $\left(-188^{* * *}\right.$ & $-0.174^{*}$ \\
& $0.145^{* * *}$ & $(1.56)$ \\
Bank Financial Variables & $(4.39)$ & 0.088 \\
Country Variables & & $(0.57)$ \\
Institutional Quality and Governance variables & YES & YES \\
Number of observations & YES & YES \\
Adjusted R2 & & YES \\
\hline
\end{tabular}


Table 4 - Trust and Deposit Volatility interaction effects

The dependent variable is the bank customer deposits scaled by the bank's total assets. The table shows the direct effects of Trust and Deposit Volatility as well as the interaction effect between Trust and Deposit Volatility. The Data Appendix provides the variable definitions and data sources. Year fixed effects are also used. *, **, *** denote statistical significance at the $10 \%, 5 \%$ and $1 \%$ levels respectively. The numbers in parentheses report the test statistic.

\begin{tabular}{lrrr}
\hline & $\begin{array}{c}\text { All } \\
\text { banks }\end{array}$ & $\begin{array}{c}\text { Domestic } \\
\text { banks }\end{array}$ & $\begin{array}{c}\text { Global } \\
\text { banks }\end{array}$ \\
\hline Culture variables & & & \\
Trust & $(3.58)$ & $(3.91)$ & $(4.47)$ \\
Individualism & $-0.229^{* * *}$ & $-0.165^{* * *}$ & -0.135 \\
Hierarchy & $(-3.71)$ & $(-5.21)$ & $(-1.37)$ \\
& $0.185^{* * *}$ & $0.126^{* * *}$ & 0.061 \\
Deposit Stability variables & $(2.97)$ & $(4.09)$ & $(0.45)$ \\
Deposit Volatility & & -0.000 & $0.001^{* * *}$ \\
Trust * Deposit Volatility & $0.001^{* * *}$ & $(-0.94)$ & $(8.01)$ \\
& $(4.00)$ & $-0.292^{* * *}$ & $-1.605^{* * *}$ \\
Bank Financial Variables & $-0.533^{* *}$ & $(-2.60)$ & $(-3.84)$ \\
Country Variables & $(-2.38)$ & YES & YES \\
Institutional Quality and Governance variables & YES & YES & YES \\
Number of observations & YES & YES & YES \\
Adjusted R2 & 1,252 & 1,053 & 199 \\
\hline
\end{tabular}


Table 5 - Robustness test - change of dependent variable to the logarithmic transformation of customer deposit balances

The dependent variable is the logarithmic transformation of the bank customer deposit balances. The Data Appendix provides the variable definitions and data sources. Year fixed effects are also used. *, $* *, * * *$ denote statistical significance at the $10 \%, 5 \%$ and $1 \%$ levels respectively. The numbers in parentheses report the test statistic.

\begin{tabular}{lrrr}
\hline & All banks & Domestic banks & Global banks \\
\hline $\begin{array}{c}\text { Culture variables } \\
\text { Trust }\end{array}$ & $0.595^{* *}$ & $0.566^{* *}$ & $0.847^{* *}$ \\
& $(2.34)$ & $(2.04)$ & $(2.02)$ \\
Individualism & $-0.642^{* * *}$ & $-0.858^{* * *}$ & -0.344 \\
Hierarchy & $(-3.00)$ & $(-3.56)$ & $(-1.01)$ \\
& $0.677^{* * *}$ & $0.625^{* * *}$ & 0.433 \\
& $(3.13)$ & $(2.70)$ & $(0.90)$ \\
Bank Financial Variables & & & YES \\
Country Variables & & & YES \\
& YES & YES & YES \\
Institutional Quality and Governance variables & YES & YES & YES \\
Number of observations & 1,298 & 1,094 & 204 \\
Adjusted R2 & 0.595 & 0.638 & 0.943 \\
\hline
\end{tabular}


Table 6 - Robustness test - Multilevel regression results using Hofstede cultural values

The dependent variable is the bank customer deposits scaled by the bank's total assets. We replace the World Values Survey cultural values of individualism, trust and hierarchy by the Hofstede values of individualism and uncertainty avoidance. The Data Appendix provides the variable definitions and data sources. Year fixed effects are also used. *, **, *** denote statistical significance at the $10 \%, 5 \%$ and $1 \%$ levels respectively. The numbers in parentheses report the test statistic. Note that the number of observations decreases (e.g., "All Banks" from 1,308 to 1,252) due to missing observations in the Hofstede cultural value scores for some countries.

\begin{tabular}{|c|c|c|c|}
\hline & $\begin{array}{c}\text { All } \\
\text { banks }\end{array}$ & $\begin{array}{c}\text { Domestic } \\
\text { banks }\end{array}$ & $\begin{array}{l}\text { Global } \\
\text { banks }\end{array}$ \\
\hline \multicolumn{4}{|l|}{ Culture variables } \\
\hline Individualism & $\begin{array}{r}-0.003 * * * \\
(-3.38)\end{array}$ & $\begin{array}{r}-0.002 * * * \\
(-3.62)\end{array}$ & $\begin{array}{l}-0.001 \\
(-0.09)\end{array}$ \\
\hline Uncertainty Avoidance & $\begin{array}{r}0.002 * * * \\
(3.52)\end{array}$ & $\begin{array}{r}0.002^{* * *} \\
(3.30)\end{array}$ & $\begin{array}{c}0.007 \\
(0.73)\end{array}$ \\
\hline Bank Financial Variables & YES & YES & YES \\
\hline Country Variables & YES & YES & YES \\
\hline Institutional Quality and Governance variables & YES & YES & YES \\
\hline Number of observations & 1,252 & 1,066 & 204 \\
\hline Adjusted R2 & 0.838 & 0.939 & 0.820 \\
\hline
\end{tabular}


We use instrumental variables regression with 2SLS which generates heteroskedasticity-robust standard errors. Panel A describes the selection process for the Instrumental Variables (IVs) we use for the endogenous regressors approximating national culture variables. The dependent variable is the ratio of customer deposits to assets. Individualism is measured as whether one believes that "incomes should be made more equal or that there should be more incentives for individual effort"; Trust is measured as whether or not most people can be trusted; Hierarchy is measured as whether one should follow instructions at work or be convinced first. National cultural values are instrumented by the fractionalization variables geography, ethnicity, language and religion (Alesina et al., 2003). The Data Appendix provides the variable definitions and data sources for all independent variables used. We have grouped these variables under the description 'Controls' for brevity. Year fixed effects are also used. *, $* *$ and $* * *$ denote significance at the $10 \%, 5 \%$ and $1 \%$ levels respectively. The numbers in parentheses report the test statistic.

\section{Panel A: Instrument Selection for Individualism, Trust, and Hierarchy}

\begin{tabular}{lrrr} 
Instruments & Individualism & \multicolumn{1}{c}{ Trust } & \multicolumn{1}{c}{ Hierarchy } \\
\hline Language & $0.143^{* * *}$ & $0.250^{* * *}$ & $-0.062^{* * *}$ \\
& $(8.59)$ & $(14.59)$ & $(-3.69)$ \\
Ethnicity & $-0.066^{* * *}$ & $-0.244^{* * *}$ & $-0.098^{* * *}$ \\
& $(-2.71)$ & $(-9.73)$ & $(-2.55)$ \\
Religion & $-0.144^{* * *}$ & $-0.168^{* * *}$ & $0.054^{* * *}$ \\
& $(-6.94)$ & $(-7.88)$ & $(2.55)$ \\
Geography & $-0.093^{* * *}$ & $-0.064^{* * *}$ & $-0.018^{* * *}$ \\
& $(-14.31)$ & $(-9.49)$ & $(-2.74)$ \\
F test & $34.31^{* * *}$ & $181.21^{* * *}$ & $24.98^{* * *}$ \\
Adjusted $\mathrm{R}^{2}$ & 0.485 & 0.836 & 0.404 \\
No. of observations & & & 1,308
\end{tabular}

Panel B: Stage 2 regression results

Individualism

Trust

Hierarchy

Controls

Year controls

Observations

Anderson under-identification test (F test)

Test of weak instruments (Hansen’s J) 